\title{
Archaeological Investigations at the Mike Myers Site (41CE481) on Bowles Creek in Cherokee County, Texas
}

Timothy K. Perttula

Heritage Research Center, Stephen F. Austin State University

Kevin Stingley

Texas Archeological Stewardship Network, Texas Historical Commission

Follow this and additional works at: https://scholarworks.sfasu.edu/ita

Part of the American Material Culture Commons, Archaeological Anthropology Commons, Environmental Studies Commons, Other American Studies Commons, Other Arts and Humanities Commons, Other History of Art, Architecture, and Archaeology Commons, and the United States History Commons

Tell us how this article helped you.

This Article is brought to you for free and open access by the Center for Regional Heritage Research at SFA ScholarWorks. It has been accepted for inclusion in Index of Texas Archaeology: Open Access Gray Literature from the Lone Star State by an authorized editor of SFA ScholarWorks. For more information, please contact cdsscholarworks@sfasu.edu. 


\section{Archaeological Investigations at the Mike Myers Site (41CE481) on Bowles Creek in Cherokee County, Texas}

\section{Creative Commons License}

\section{(c) (1) \&}

This work is licensed under a Creative Commons Attribution-NonCommercial 4.0 International License 


\title{
Archaeological Investigations at the Mike Myers Site (41CE481) on Bowles Creek in Cherokee County, Texas
}

\author{
Timothy K. Perttula and Kevin Stingley
}

\section{Introduction and Site Setting}

The Mike Myers site is a multiple component prehistoric site in the Bowles Creek valley in the Neches River basin in East Texas (Figure 1). The site is on an upland landform (400 ft. amsl), now a pasture with low surface visibility, between Bowles Creek to the east ca. $100 \mathrm{~m}$ and a spring-fed branch to the west. The confluence of Bowles Creek with Jackson Branch lies ca. $600 \mathrm{~m}$ to the south. Soils on the site are classified as Nacogdoches fine sandy loam (Mowery and Oakes 1959). Based on the archaeological investigations conducted at the site to date, the known site area covers a ca. $150 \times 60 \mathrm{~m}$ area (north-south and east-west) or approximately 2 acres, but the site may well extend to the south onto a lower upland ridge slope (390 ft. amsl) some distance; hopefully shovel tests can be excavated in this area in the near future to determine the full site boundaries.

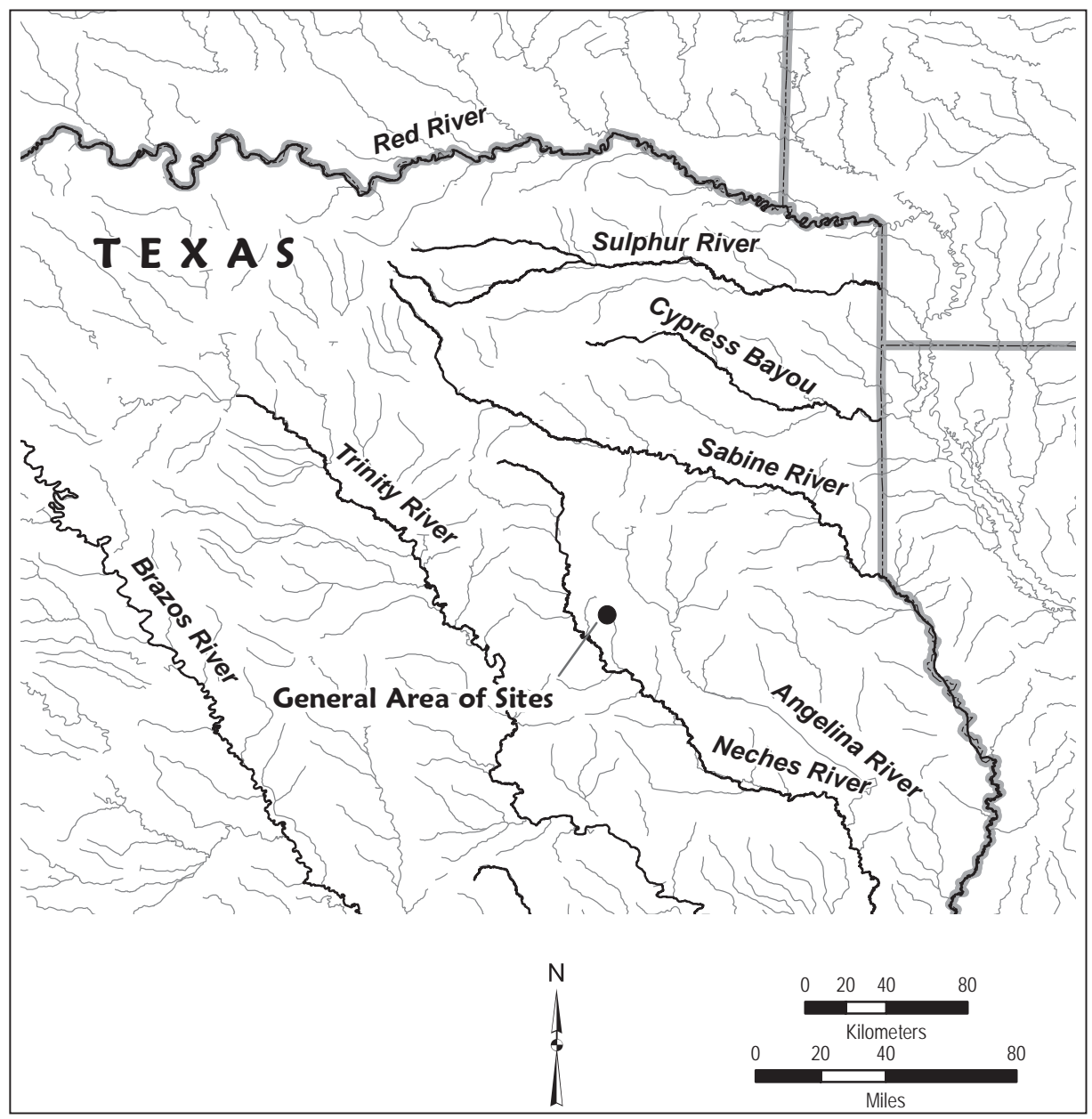

Figure 1. General location of the Mike Myers site (41CE481) and other recently investigated sites in the Bowles Creek valley, Cherokee County, Texas. 
This article discusses the archaeological findings obtained to date from 2016 archaeological investigations at the Mike Myers site, much of it consisting of shovel tests across the site area, focusing particularly on the archaeological remains recovered in the work that date from Woodland and Caddo periods. Most notably, the shovel test work at the site recovered two sherds of non-tempered early Woodland period Tchefuncte pottery. As far as we are aware, this is only the second site in East Texas where Tchefuncte pottery has been found; the other site is the well-known Resch site (41HS16) in the Sabine River basin in Harrison County, Texas (Webb et al. 1969). Tchefuncte culture pottery has been recovered from the Louisiana Gulf Coast, in the Ouachita and Mississippi river basins in Mississippi, Louisiana, and southeast Arkansas, and in the Sabine Lake area of coastal Texas and Louisiana (Hays and Weinstein 2010:Figure 6.3; Aten and Bollich 2011:Figure 1), more than $250 \mathrm{~km}$ east and southeast of the Mike Myers site.

\section{Archaeological Investigations}

A general site surface collection and the excavation of ST 101-105 were done in February 2016, when the site was first identified and recorded by Stingley. ST 1-24 and ST 30-46 were then excavated in October and November 2016 by Stingley, with the assistance of Mark Walters, and these were concentrated in the southern part of the site and north of the property fence line (Figure 2a-b). Descriptions of the sediments in the shovel tests are provided in Table 1.

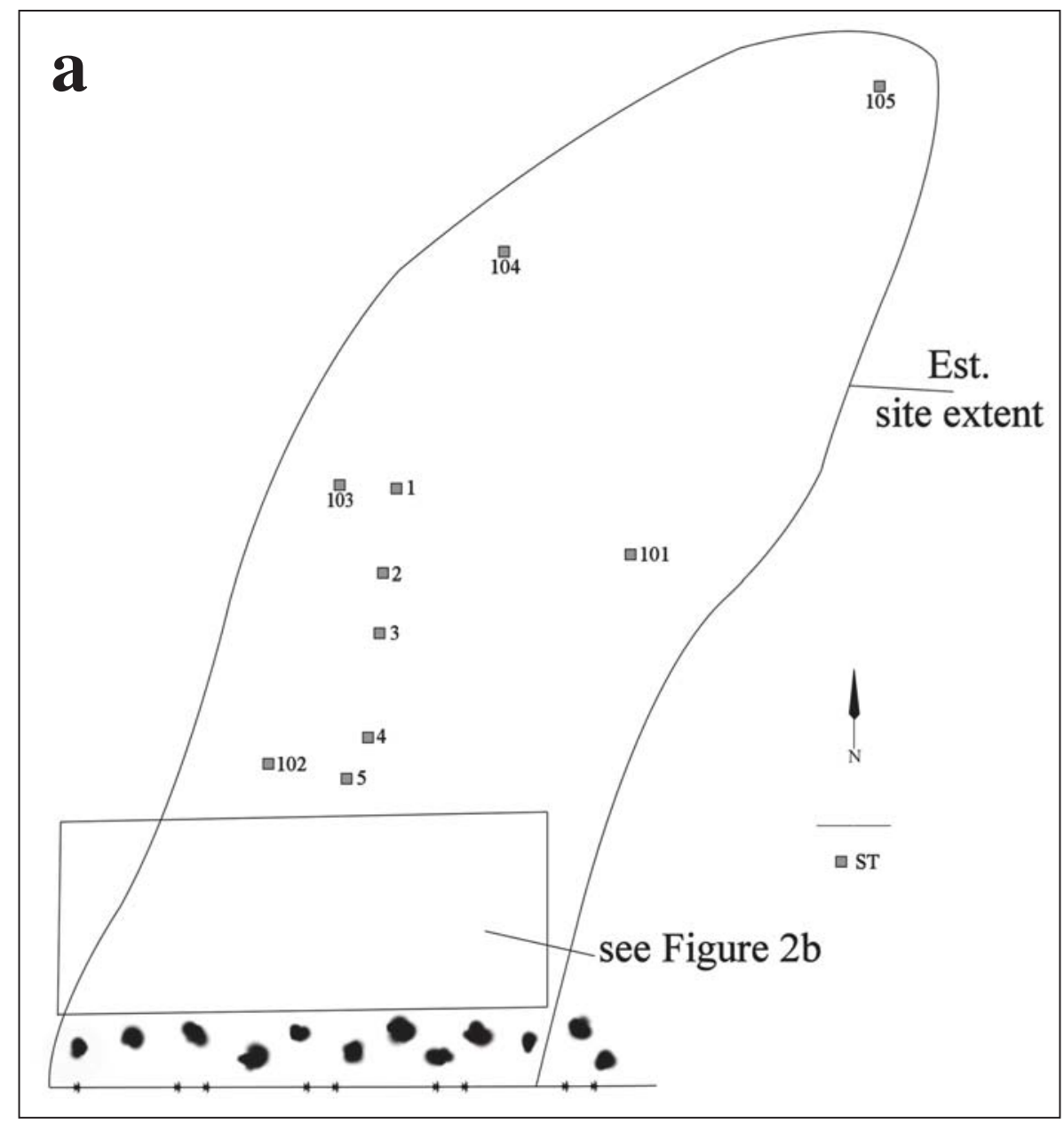

Figure 2. Location of excavated shovel tests and Units 1-3 at the Mike Myers site: a, entire known site area; b, enlarged area of shovel tests around Units 1-3. 


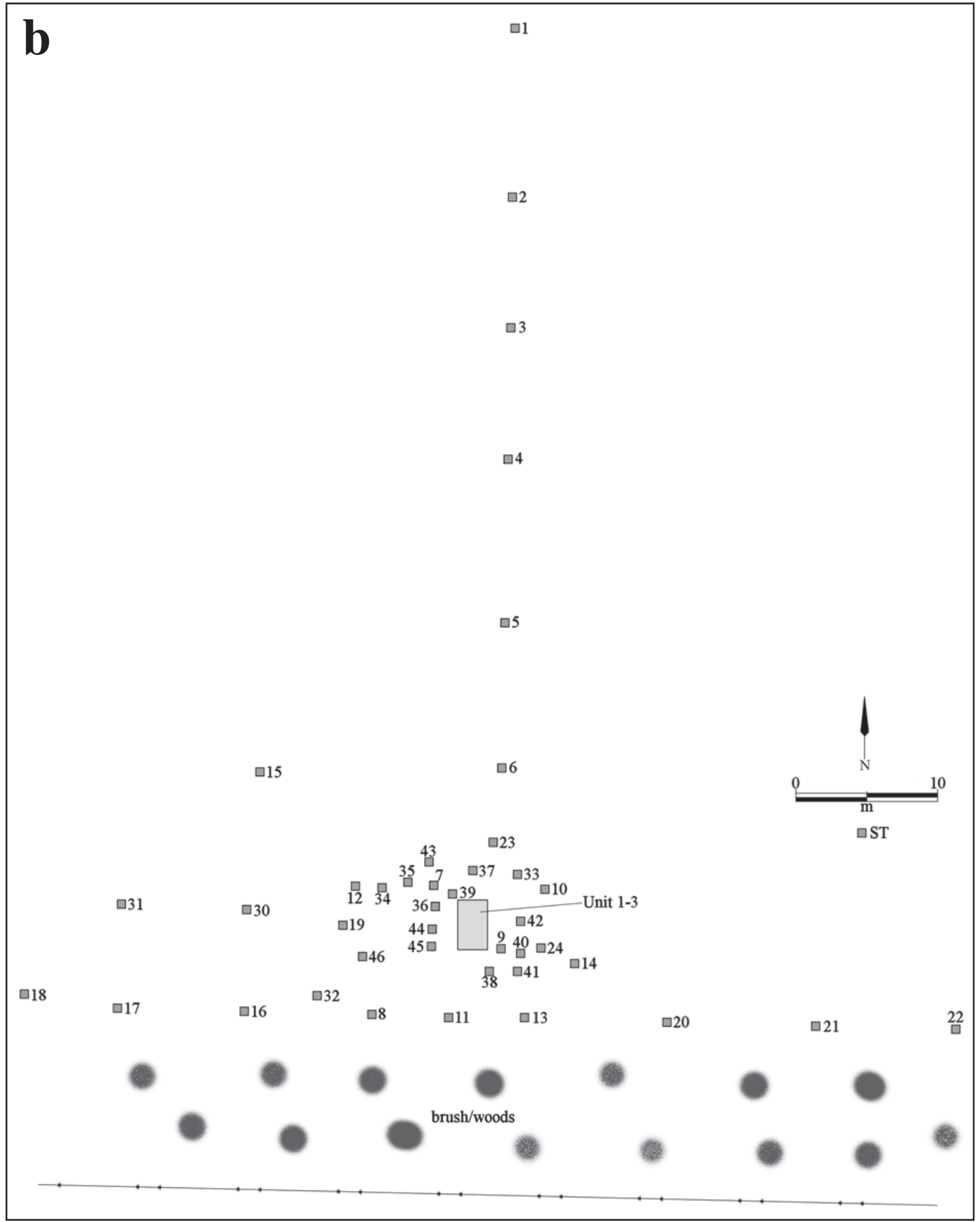


Table 1. Descriptions of the sediments in shovel tests at the Mike Myers site (41CE481).

ST No. Description

101

102

103

104

105

1

2

3

4

5

6

7

8

9

10

11

12

13

14

15

16

17

18

19

20

21

22

23

24

30

31

32

33

34

35

36

37

38

39

40

41

42

43

44

45

46
0-22 cm, reddish brown sandy loam; $22-26 \mathrm{~cm}+$, reddish-brown sandy clay

0-62 cm, reddish-brown sandy loam; 62-66 cm+, reddish-brown sandy clay

0-25 cm, reddish-brown sandy loam; $25-28 \mathrm{~cm}+$, reddish-brown sandy clay

0-30 cm, reddish-brown sandy loam; 30-33 cm+, reddish-brown sandy clay

0-20 cm, reddish-brown sandy loam; 20-23 cm+, reddish-brown sandy clay

0-40 $\mathrm{cm}+$, reddish-brown sandy loam

0-37 cm, reddish-brown sandy loam; 37-40 $\mathrm{cm}+$, reddish-brown sandy clay 0-73 cm, reddish-brown sandy loam; 73-80 cm+, reddish-brown sandy clay 0-32 cm, reddish-brown sandy loam; 32-35 cm+, reddish-brown sandy clay 0-65 cm, reddish-brown sandy loam; 65-68 cm+, reddish-brown sandy clay 0-60 cm, reddish-brown sandy loam; 60-63 cm+, reddish-brown sandy clay 0-66 cm, reddish-brown sandy loam; 66-70 cm+, reddish-brown sandy clay 0-72 cm, reddish-brown sandy loam; 72-75 cm+, reddish-brown sandy clay 0-93 cm, reddish-brown sandy loam; 93-95 cm+, reddish-brown sandy clay 0-85 cm, reddish-brown sandy loam; $85-88 \mathrm{~cm}+$, reddish-brown sandy clay $0-100 \mathrm{~cm}+$, reddish-brown sandy loam

0-60 cm, reddish-brown sandy loam; 60-66 cm+, reddish-brown sandy clay 0-87 cm, reddish-brown sandy loam; 87-93 cm+, reddish-brown sandy clay 0-75 cm, reddish-brown sandy loam; 75-78 $\mathrm{cm}+$, reddish-brown sandy clay $0-60 \mathrm{~cm}+$, reddish-brown sandy loam

0-80 cm, reddish-brown sandy loam; $80 \mathrm{~cm}+$, reddish-brown sandy clay 0-70 cm, reddish-brown sandy loam; 70-74 $\mathrm{cm}+$, reddish-brown sandy clay 0-60 cm, reddish-brown sandy loam; $60 \mathrm{~cm}+$, reddish-brown sandy clay $0-80 \mathrm{~cm}$, reddish-brown sandy loam; $80 \mathrm{~cm}+$, reddish-brown sandy clay $0-33 \mathrm{~cm}+$, reddish-brown sandy loam

$0-47 \mathrm{~cm}+$, reddish-brown sandy loam

$0-46 \mathrm{~cm}+$, reddish-brown sandy loam

0-76 cm, reddish-brown sandy loam; 76-80 cm+, reddish-brown sandy clay 0-80 cm, reddish-brown sandy loam; 80-85 cm+, reddish-brown sandy clay $0-55 \mathrm{~cm}$, reddish-brown sandy loam; $55 \mathrm{~cm}+$, reddish-brown sandy clay 0-60 cm, reddish-brown sandy loam; 60-64 cm+, reddish-brown sandy clay 0-60 cm, reddish-brown sandy loam; 60-65 cm+, reddish-brown sandy clay 0-80 cm, reddish-brown sandy loam; 80-85 $\mathrm{cm}+$, reddish-brown sandy clay $0-80 \mathrm{~cm}$, reddish-brown sandy loam; $80 \mathrm{~cm}+$, reddish-brown sandy clay 0-75 cm, reddish-brown sandy loam; 75-78 cm+, reddish-brown sandy clay $0-85 \mathrm{~cm}$, reddish-brown sandy loam; $85 \mathrm{~cm}+$, reddish-brown sandy clay 0-60 cm, reddish-brown sandy loam; 60-65 cm+, reddish-brown sandy clay 0-90 cm, reddish-brown sandy loam; $90-95 \mathrm{~cm}+$, reddish-brown sandy clay $0-80 \mathrm{~cm}$, reddish-brown sandy loam; $80 \mathrm{~cm}+$, reddish-brown sandy clay $0-100 \mathrm{~cm}+$, reddish-brown sandy loam

$0-100 \mathrm{~cm}+$, reddish-brown sandy loam $0-100 \mathrm{~cm}+$, reddish-brown sandy loam 0-77 cm, reddish-brown sandy loam; 77-80 cm+, reddish-brown sandy clay $0-80 \mathrm{~cm}$, reddish-brown sandy loam; $80 \mathrm{~cm}+$, reddish-brown sandy clay $0-80 \mathrm{~cm}$, reddish-brown sandy loam; $80 \mathrm{~cm}+$, reddish-brown sandy clay 0-72 cm, reddish-brown sandy loam; $72-75 \mathrm{~cm}+$, reddish-brown sandy clay 
The depth of the Nacogdoches fine sandy loam A- horizon at the site ranges from less than $35 \mathrm{~cm}$ in shovel tests at the northern and southeastern ends of the landform to as great as $100 \mathrm{~cm}$ in thickness in a ca. 55 x $40 \mathrm{~m}$ area in the central and southern parts of the known site boundaries. The B-horizon is a reddish-brown sandy clay (see Table 1).

In the midst of shovel testing, a 3 x $1 \mathrm{~m}$ unit (Units 1-3) was excavated in arbitrary $10 \mathrm{~cm}$ levels by Kevin Stingley, Tom Middlebrook, Ron Coleman, and Morris Jackson in the immediate vicinity of ST 7 and ST 9, where Early Woodland period Tchefuncte ceramic sherds had been recovered (see below). Here, reddish-brown sandy loam sediments between 60 and $70 \mathrm{~cm}$ in thickness were exposed overlying the sandy clay B-horizon. No features were noted in the walls or floors of the units. Excavations of ST 15 , about 15 m northwest of Units 1-3, hit what may have been a complete brushed bowl.

All told, more than 1190 artifacts have been recovered in the various investigations at the Mike Myers site (Table 2), including 78 artifacts from the February 2016 surface collection. More than 55 percent are pieces of lithic debris, another 24 percent are plain and decorated ceramic vessel sherds, and 16 percent are burned animal bones. Other recovered artifacts include several kinds of chipped stone tools, a small number of wood charcoal pieces, and fragments of charred nutshells.

Table 2. Distribution of Artifacts at the Mike Myers site (41CE481).

\begin{tabular}{|c|c|c|c|c|c|c|c|c|c|c|}
\hline Prov. & PS & $\mathrm{DS}$ & $\mathrm{AP}$ & $\mathrm{DP}$ & Bif & FT & LD & $\mathrm{AB}$ & $\begin{array}{l}\text { WC/ } \\
\text { NS }\end{array}$ & $\mathrm{N}$ \\
\hline Surface & 28 & 19 & 2 & - & - & 1 & 28 & - & $-/-$ & 78 \\
\hline ST 2 & 2 & 1 & - & - & - & - & 5 & - & $-/-$ & 8 \\
\hline ST 3 & 5 & 1 & 1 & - & - & - & 7 & - & $-/-$ & 14 \\
\hline ST 4 & 2 & 2 & - & - & - & - & - & - & $-/-$ & 4 \\
\hline ST 5 & 2 & 3 & - & - & - & - & - & - & $-/-$ & 5 \\
\hline ST 6 & 3 & - & - & - & - & - & 2 & - & $-/-$ & 5 \\
\hline ST 7 & 6 & $4 *$ & - & - & - & - & 3 & - & $-/-$ & 13 \\
\hline ST 8 & 1 & - & - & - & - & - & 8 & - & $-/-$ & 9 \\
\hline ST 9 & 5 & $5^{*}$ & - & 2 & - & - & 13 & 1 & $-/-$ & 26 \\
\hline ST 10 & 6 & - & - & - & - & - & 5 & - & $-/-$ & 11 \\
\hline ST 11 & 1 & - & - & - & - & - & 8 & - & $-/-$ & 9 \\
\hline ST 12 & 4 & - & - & - & - & - & 5 & - & $-/-$ & 9 \\
\hline ST 13 & 2 & - & - & 1 & - & - & 14 & 20 & $4 /-$ & 41 \\
\hline ST 14 & 1 & - & - & - & - & - & 12 & 4 & $2 /-$ & 19 \\
\hline ST 15 & 3 & 1 & - & - & - & - & 19 & - & $-/-$ & 23 \\
\hline ST 16 & 3 & - & - & - & - & - & 17 & 6 & $-/-$ & 26 \\
\hline ST 17 & 4 & 1 & - & - & - & - & 14 & 3 & $-/ 3$ & 25 \\
\hline ST 18 & - & - & - & - & - & - & 14 & 6 & $1 / 1$ & 22 \\
\hline ST 19 & 5 & - & - & - & - & - & 18 & 13 & $-/ 1$ & 37 \\
\hline ST 20 & 1 & - & - & - & - & - & 6 & - & $-/-$ & 7 \\
\hline ST 21 & - & - & - & - & - & - & 9 & 20 & $-/-$ & 29 \\
\hline ST 22 & - & - & - & - & - & - & 2 & - & $-/-$ & 2 \\
\hline ST 23 & 2 & - & - & - & - & - & 7 & 3 & $-/-$ & 12 \\
\hline ST 24 & 5 & - & - & 1 & - & - & 8 & 1 & $-/ 1$ & 16 \\
\hline ST 30 & - & 1 & - & - & - & 1 & 10 & 8 & $-/-$ & 20 \\
\hline ST 31 & 4 & 2 & - & 1 & - & - & 11 & 2 & $-1-$ & 20 \\
\hline ST 32 & 5 & 2 & - & 1 & 2 & - & 13 & 1 & $1 / 1$ & 26 \\
\hline ST 33 & - & - & - & - & - & - & 6 & - & $-/-$ & 6 \\
\hline ST 34 & 1 & - & - & - & 1 & - & 4 & - & $-/-$ & 6 \\
\hline
\end{tabular}


Table 2. Distribution of Artifacts at the Mike Myers site (41CE481), cont.

\begin{tabular}{lllllllllll}
\hline Prov. & PS & DS & AP & DP & Bif & FT & LD & AB & WC/ & N \\
& & & & & & & & & NS \\
\hline ST 35 & - & 1 & - & - & - & - & 5 & - & $-/ 1$ & 7 \\
ST 36 & 1 & 1 & - & - & - & 1 & 6 & - & $1 / 1$ & 11 \\
ST 37 & 2 & - & - & 1 & - & - & 10 & - & $-/ 1$ & 14 \\
ST 38 & - & 1 & - & - & - & - & 12 & 3 & $1 /-$ & 17 \\
ST 39 & - & 1 & - & - & - & - & 3 & - & $-/-$ & 4 \\
ST 40 & 7 & 1 & - & - & - & - & 13 & 4 & $-/-$ & 25 \\
ST 41 & 4 & - & 1 & - & - & - & 12 & 3 & $-/-$ & 20 \\
ST 42 & 3 & 2 & - & - & - & 1 & 7 & 2 & $-/-$ & 15 \\
ST 43 & 4 & - & - & - & - & - & 6 & 2 & - & 12 \\
ST 44 & 1 & - & - & - & - & - & 6 & 5 & $-/-$ & 12 \\
ST 45 & 4 & 1 & - & - & - & - & 13 & 1 & $-/ 2$ & 21 \\
ST 46 & 9 & 1 & - & - & - & - & 11 & 7 & $-/-$ & 28 \\
ST 101 & 1 & 6 & - & - & - & - & - & - & $-/-$ & 7 \\
ST 102 & 1 & 1 & - & - & 1 & - & 6 & - & $-/-$ & 9 \\
ST 103 & 2 & 3 & - & - & - & - & 2 & - & $-/-$ & 7 \\
ST 104 & - & 5 & - & - & - & - & 1 & - & $-/-$ & 6 \\
ST 105 & 2 & 1 & - & - & - & - & - & - & $-/-$ & 3 \\
& & & & & & & & & & \\
Unit 1 & 15 & 9 & 1 & 1 & - & - & 102 & 25 & $1 / 3$ & 157 \\
Unit 2 & 19 & 7 & - & - & - & 1 & 88 & 27 & $1 / 1$ & 144 \\
Unit 3** & 19 & 9 & - & - & - & - & 83 & 29 & $-/ 6$ & 146 \\
\hline Totals & 195 & 92 & 5 & 8 & 4 & 5 & 654 & 196 & $12 / 22$ & 1193 \\
\hline
\end{tabular}

*Includes Lake Borgne Incised sherds

**does not include 1 FCR

$\mathrm{PS}=$ plain sherd; $\mathrm{DS}=$ decorated sherd; $\mathrm{AP}=$ arrow point; $\mathrm{DP}=$ dart point; $\mathrm{BIF}=$ biface; $\mathrm{FT}=$ flake tool; $\mathrm{LD}=$ lithic debris; $\mathrm{AB}=$ animal bone; $\mathrm{WC}=$ wood charcoal; $\mathrm{NS}=$ nutshell

In the shovel tests, the mean density of artifacts per shovel test is 16.6, or ca. 133 artifacts per square meter. The highest densities are in ST 13 ( $\mathrm{n}=41$ or ca. 328 artifacts per square meter) and ST 19 (n=37 or ca. 296 artifacts per square meter) to the south and southwest of Units 1-3. Other shovel tests with densities above 200 artifacts per square meter are ST 9, ST 16, ST 17, ST 21, ST 32, and ST 46, again located either to the southeast or southwest about $10 \mathrm{~m}$ distance from Units 1-3.

The highest densities of burned animal bones occur in a $60 \times 15 \mathrm{~m}$ area at the southern end of the site, and this same area includes all the shovel tests that had nutshells in their archaeological deposits. Shovel tests with the highest densities of plain and decorated sherds also occur in this part of the site (Figure 3a-c), as does the lithic debris (Figure 3d). The dart points are also from this part of the site (see Table 2).

By depth, about 87 percent of the artifacts recovered in the shovel tests are from $0-60 \mathrm{~cm}$ bs (Table 3 ), but artifacts have been recovered to $100 \mathrm{~cm}$ bs. Ceramic vessel sherds are most abundant between 0-40 cm bs ( 87 percent of the sherds are from these depths), as is also the case for the lithic debris and bifaces, while arrow points and dart points in the shovel tests are concentrated between 40-60 $\mathrm{cm}$ bs (although one dart point came from $80-100 \mathrm{~cm}$ bs); 67 percent of the flake tools came from $60-80 \mathrm{~cm}$ bs. Burned animal bone was recovered in all levels in the shovel tests, with the highest numbers found between $20-80 \mathrm{~cm}$ bs; proportionally by level, animal bone is most abundant between $60-80 \mathrm{~cm}$ bs. Wood charcoal came from $20-80 \mathrm{~cm}$ bs in the archaeological deposits, while 92 percent of the recovered nutshell was found between $40-60 \mathrm{~cm}$ bs; the one remaining piece of nutshell came from $80-100 \mathrm{~cm}$ bs. 


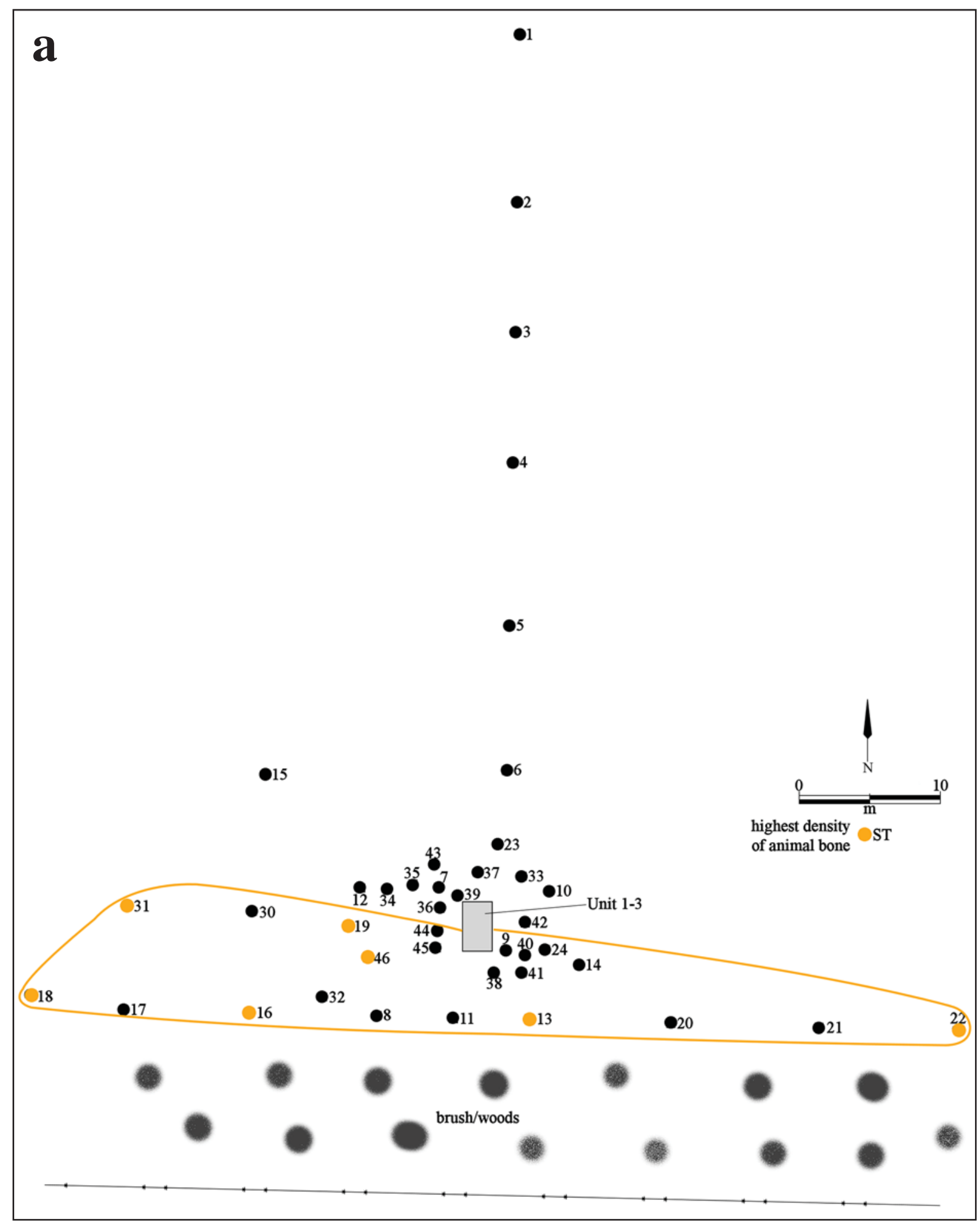

Figure 3. Distribution of the shovel tests with the highest densities of artifacts at the Mike Myers site: a, animal bones; $b$, charred nutshells; c, plain and decorated sherds; $d$, lithic debris. 


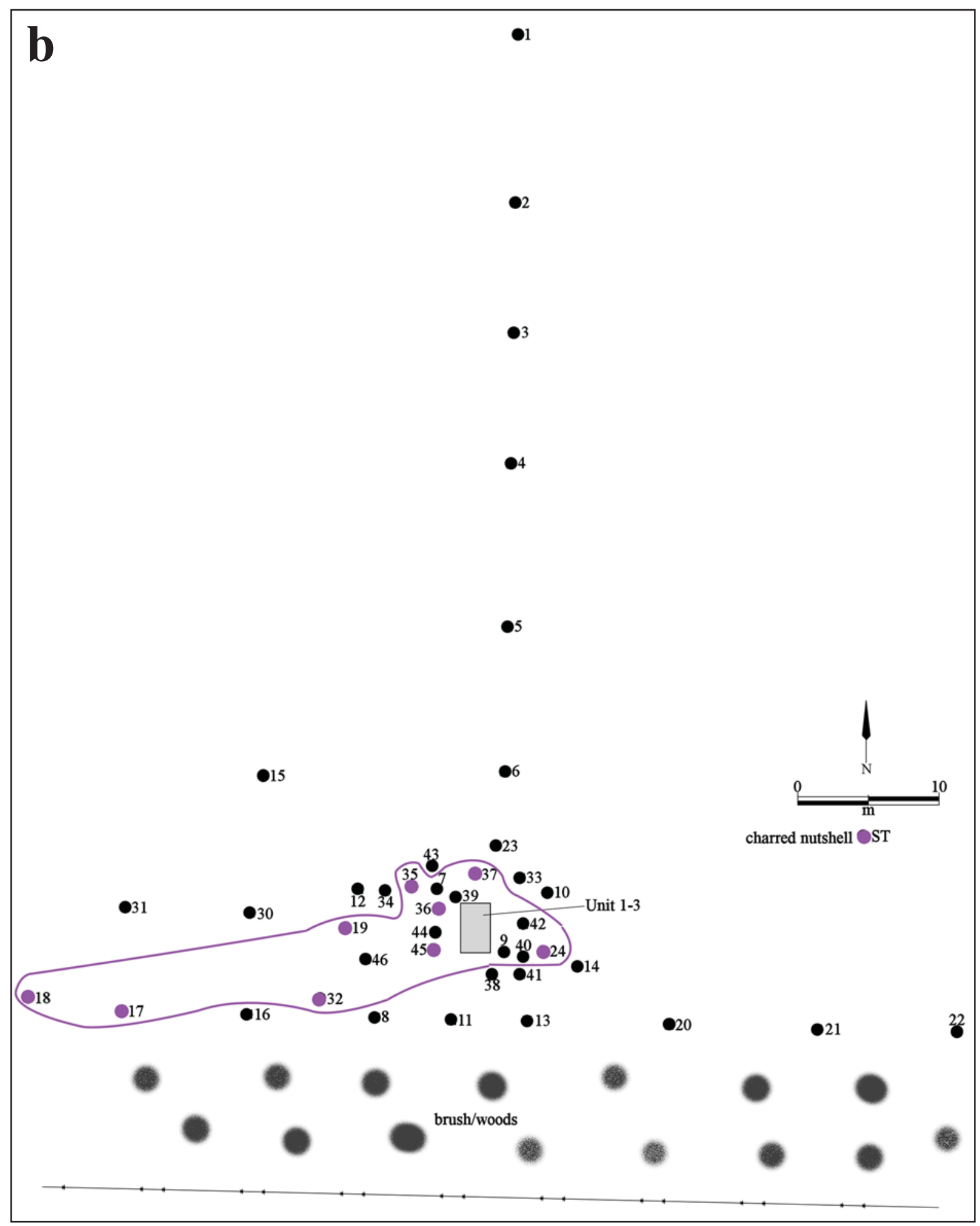




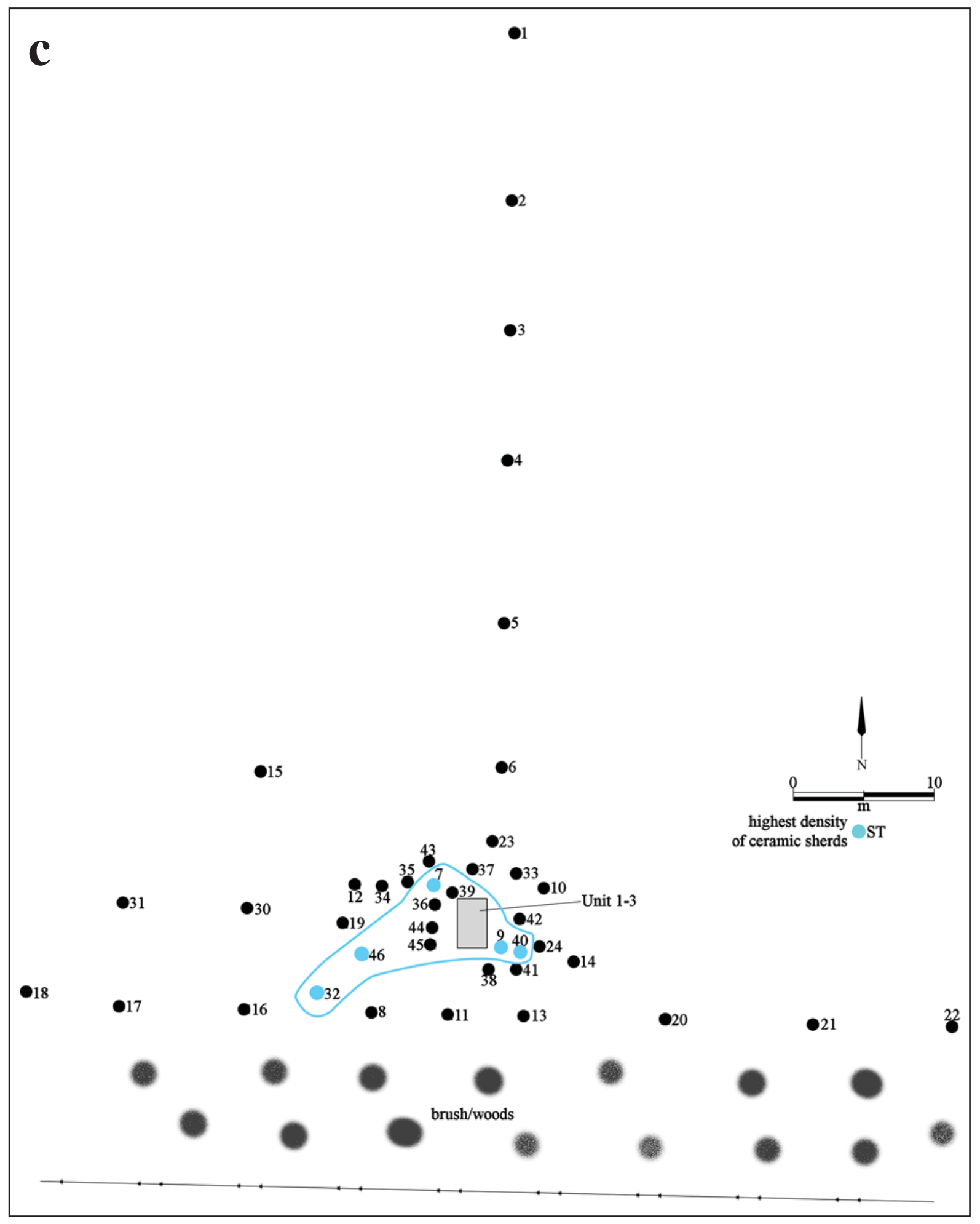




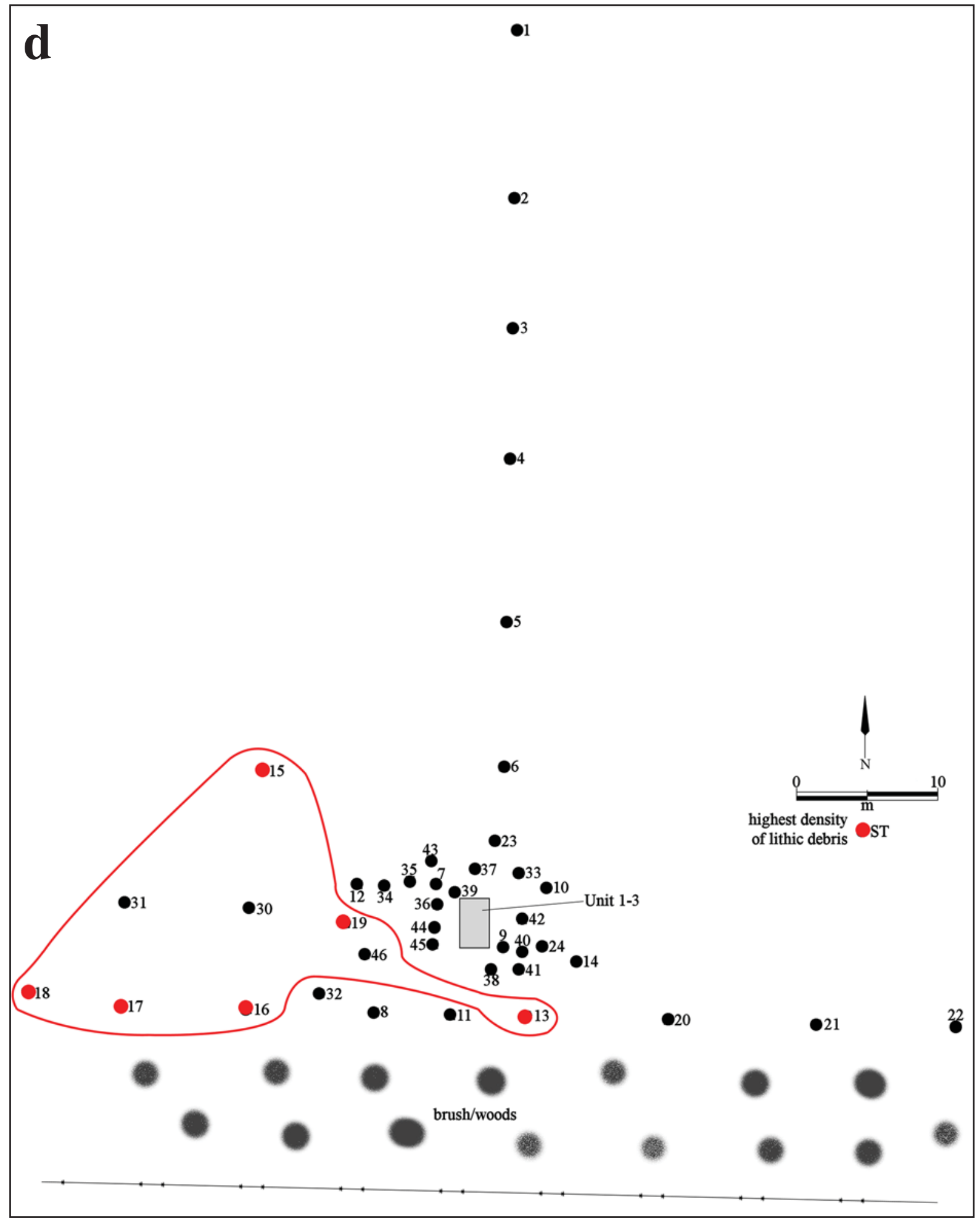


Table 3. Distribution of artifacts by depth in shovel tests at the Mike Myers site (41CE481).

\begin{tabular}{lllllll}
\hline Artifact Category & $0-20$ & $20-40$ & $\begin{array}{l}40-60 \\
\mathrm{~cm} \text { bs }\end{array}$ & $60-80$ & $80-100$ & $\mathrm{~N}$ \\
\hline PS & 52 & 45 & 9 & 6 & - & 112 \\
DS & 28 & 16 & 5 & 1 & 2 & 52 \\
AP & - & - & 2 & - & - & 2 \\
DP & - & 1 & 5 & - & 1 & 7 \\
BIF & 1 & 1 & 1 & - & - & 3 \\
FT & - & 1 & - & 2 & - & 353 \\
LD & 6 & 100 & 83 & 34 & 7 & 114 \\
AB & - & 6 & 2 & 2 & 3 & 12 \\
WC & - & - & 11 & - & 1 & 668 \\
NS & 216 & 212 & 152 & 74 & 14 & 12 \\
\hline Totals & & & & & & \\
\hline
\end{tabular}

$\mathrm{PS}=$ plain sherd; $\mathrm{DS}=$ decorated sherd; $\mathrm{AP}=$ arrow point; $\mathrm{DP}=$ dart point; $\mathrm{BIF}=$ biface; $\mathrm{FT}=$ flake tool; $\mathrm{LD}=$ lithic debris; $\mathrm{AB}=$ animal bone; $\mathrm{WC}=$ wood charcoal; $\mathrm{NS}=$ nutshell

The mean density of artifacts in Units 1-3 is 149 per square meters, with a range between 144-157 per square meter (see Table 2). By depth, the recovered artifacts are most abundant between $20-50 \mathrm{~cm}$ bs (Table 4) in these archaeological deposits, but artifacts are present in all levels between 0-70 cm bs. Plain and decorated sherds are most common between 10-40 cm bs, while the highest frequencies of lithic debris are between $20-40 \mathrm{~cm}$ bs. Animal bone is present throughout the archaeological deposits, but are concentrated between $40-70 \mathrm{~cm}$ bs. The only recovered wood charcoal pieces in Units 1-3 came from 40$50 \mathrm{~cm}$ bs, while charred nutshells are also concentrated between $40-50 \mathrm{~cm}$ bs.

Table 4. Distribution of artifacts by depth in Units 1-3 at the Mike Myers site (41CE481).

\begin{tabular}{lllllllll}
\hline Artifact category & $0-10$ & $10-20$ & $20-30$ & $\begin{array}{l}30-40 \\
\mathrm{~cm} \text { bs }\end{array}$ & $40-50$ & $50-60$ & $60-70$ & $\mathrm{~N}$ \\
\hline PS & 5 & 9 & 20 & 13 & 2 & 3 & 2 & 54 \\
DS & 2 & 10 & 6 & 3 & 1 & - & 2 & 24 \\
AP & - & 1 & - & - & - & - & - & 1 \\
DP & 1 & - & - & - & - & - & - & 1 \\
FT & - & 1 & - & - & - & - & - & 1 \\
LD & 24 & 39 & 65 & 43 & 44 & 26 & 32 & 273 \\
FCR & - & - & 1 & - & - & - & - & 1 \\
AB & 1 & 10 & 8 & 19 & 20 & 11 & 12 & 81 \\
WC & - & - & - & - & 2 & - & - & 2 \\
NS & - & - & - & 2 & 7 & - & 1 & 10 \\
\hline Totals & 33 & 70 & 100 & 80 & 80 & 40 & 49 & 448 \\
\hline
\end{tabular}

$\mathrm{PS}=$ plain sherd; $\mathrm{DS}=$ decorated sherd; $\mathrm{AP}=$ arrow point; $\mathrm{DP}=$ dart point; $\mathrm{BIF}=$ biface; $\mathrm{FT}=$ flake tool; $\mathrm{LD}=$ lithic debris; $\mathrm{FCR}=$ fire-cracked rock; $\mathrm{AB}=$ animal bone; $\mathrm{WC}=$ wood charcoal; $\mathrm{NS}=$ nutshell 


\section{Recovered Artifacts from Investigations at the Myers Site (41CE481)}

The recovered artifacts from archaeological investigations at the Myers site include plain and decorated ceramic vessel sherds, chipped stone tools (including arrow points, dart points, bifaces, and flake tools), lithic debris, fire-cracked rock, and organic remains. The latter is comprised of burned animal bones, wood charcoal, and charred nutshells. Lithic debris accounts for about 55 percent of the recovered materials, followed by ceramic vessel sherds ( 24 percent), and animal bones (16 percent).

\section{Ceramic Sherds}

Of the 287 ceramic vessel sherds recovered in the archaeological investigations at the Mike Myers site, 270 (94 percent) sherds are from tempered Caddo ceramic wares. The remainder ( $n=17$ or 6 percent) are from Woodland period sandy paste Goose Creek Plain sherds or non-tempered laminated Tchefuncte ceramic sherds (Table 5). The Caddo sherds are from grog-tempered (77.4 percent), grog-bone-tempered (15.5 percent), and bone-tempered (7.0 percent) vessels; 22.5 percent of the tempered Caddo sherds have some amount of burned bone inclusions, either in combination with crushed sherds (grog), or as the sole temper.

Table 5. Use of Temper in Ceramic Vessel Sherds at the Mike Myers site (41CE481).

\begin{tabular}{lllllll}
\hline Ware & grog & grog-bone & bone & SP & None* & N \\
\hline Plain & 133 & 35 & 12 & 14 & - & 194 \\
Utility & 57 & 4 & 6 & - & - & 67 \\
Fine & 19 & 3 & 1 & - & - & 23 \\
Tchefuncte & - & - & - & - & 3 & 3 \\
\hline Totals & 209 & 42 & 19 & 14 & 3 & 287 \\
\hline
\end{tabular}

*laminated

SP=sandy paste (i.e., Goose Creek Plain, var. unspecified, see Aten 1983 and Story 1990)

The plain to decorated sherd ratio in the Caddo ceramic assemblage from the Mike Myers site is 2.00 $(\mathrm{n}=180 / 90)$, and approximately 74 percent of the decorated sherds are from utility wares. Other metrics for the assemblage include the Brushed to Plain Sherd Ratio (B/Pl) of 0.26 and the Brushed to Other Wet Paste Sherds Ratio of $1.31(\mathrm{n}=46 / 35)$.

Among the Caddo ceramic utility wares at the site, brushed, brushed-incised, and brushed-punctated rim and body sherds from Bullard Brushed vessels comprise approximately 69 percent of the assemblage (Table 6). Sherds with simple incised decorative elements account for another 15 percent of the utility wares, and these are likely from Maydelle Incised jars. Another 10.5 percent have rows of fingernail or tool punctations on vessel bodies. The remainder of the utility wares include one appliqued body sherd (1.5 percent), one body sherd with pinched ridges (1.5 percent), and a body sherd with parallel grooves (1.5 percent). This sherd is from a Lindsey Grooved jar, and such vessels are found in this part of the Neches River basin in Historic Caddo Allen phase contexts (postdating ca. A.D. 1680), indicating some use of the Mike Myers site at that time. Only one other decorated sherd in the assemblage, including the fine wares, is from an Historic Caddo ceramic type (see below). 
Table 6. Decorative elements on Ancestral Caddo Utility and Fine Wares at the Mike Myers site (41CE481), and Tchefuncte Wares.

\begin{tabular}{llll}
\hline Decorative Method and Element & Rim & Body & N \\
\hline
\end{tabular}

\section{$\underline{\text { Utility Ware }}$}

Lake Borgne Incised*

Appliqued

appliqued node

1

\section{Brushed}

horizontal brushed

opposed brushed

overlapping brushed

parallel brushed

vertical brushed

\section{1}

$-$

$-$

$-$

$-$

\section{Brushed-Incised}

parallel brushed-incised marks and lines

parallel brushed and overlying parallel incised lines

$\begin{array}{lll}- & 10 & 10 \\ - & 1 & 1\end{array}$

\section{Brushed-Punctated}

horizontal brushed above fingernail punctated rows

horizontal brushed above tool punctated row

parallel brushed with fingernail punctates through the brushing

$\begin{array}{lll}- & 1 & 1 \\ - & 1 & 1 \\ - & 1 & 1\end{array}$

\section{Grooved}

parallel grooved lines

Incised

cross-hatched incised lines

curvilinear incised lines

parallel incised lines

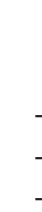

\section{Pinched}

parallel pinched ridges

$\begin{array}{lll}- & 1 \\ - & 1\end{array}$

\section{Punctated}

fingernail punctated rows

single tool punctate

tool punctated rows

$2-2$

\section{Fine Ware}

Engraved

curvilinear and parallel engraved lines curvilinear hatched zone/zones diagonal engraved lines diagonal hatched zone horizontal engraved line parallel engraved lines rectilinear engraved el.

$\begin{array}{lll}- & 1 & 1 \\ - & 3 & 3 \\ 1 & 1 & 2 \\ - & 1 & 1 \\ - & 1 & 1 \\ - & 6^{* *} & 6 \\ - & 1 & 1\end{array}$


Table 6. Decorative elements on Ancestral Caddo Utility and Fine Wares at the Mike Myers site (41CE481), and Tchefuncte Wares, cont.

\begin{tabular}{llll}
\hline Decorative Method and Element & Rim & Body & N \\
\hline straight engraved line & - & $6^{* *}$ & 6 \\
straight-diagonal engraved lines & - & 1 & 1 \\
$\begin{array}{l}\text { Trailed } \\
\text { horizontal trailed lines }\end{array}$ & 1 & - & 1 \\
\hline Totals & 4 & 87 & 91 \\
\hline
\end{tabular}

*Tchefuncte ware

**one sherd each with red pigment rubbed in engraved lines

The fine ware sherds in the Mike Myers decorated sherd assemblage include sherds from vessels with either engraved $(n=22)$ or trailed $(n=1)$ decorative elements (see Table 6); two of the engraved sherds have a red clay pigment rubbed in the engraved lines. The trailed sherd is likely from a post-A.D. 1680 Keno Trailed vessel.

Other than straight, straight-diagonal, horizontal, and parallel engraved lines on body sherds, the remainder of the decorative elements feature curvilinear and parallel engraved lines (Figure 4a), curvilinear hatched zones (Figure 4b-d), diagonal engraved lines (Figure 4e), diagonal hatched zones (Figure 4f), or rectilinear engraved lines (see Table 6). None of these decorative elements can be definitively linked with a recognized fine ware type, although hatched zones on fine ware sherds in the Neches River basin are noted in both Middle (ca. A.D. 1200-1400) and Late Caddo (ca. A.D. 1400-1680) assemblages.

The ceramic assemblage from the Mike Myers is notable for the considerable proportion of brushed sherds ( 51 percent) in the decorated sherd assemblage, from Bullard Brushed vessels, which suggests a post-A.D. 1250-1300 Caddo occupation, one that took place after the core area of the George C. Davis mound center and village, located a few miles south at the confluence of Bowles Creek and the Neches River, was no longer permanently occupied by Caddo peoples. The absence of post-A.D. 1400 Poynor Engraved or post-A.D. 1680 Patton Engraved fine ware sherds in the 41CE289 assemblage, along with selected ceramic metrics (Table 7), also suggests the site was settled by Caddo peoples prior to ca. A.D. 1400, likely between ca. A.D. 1300-1400.

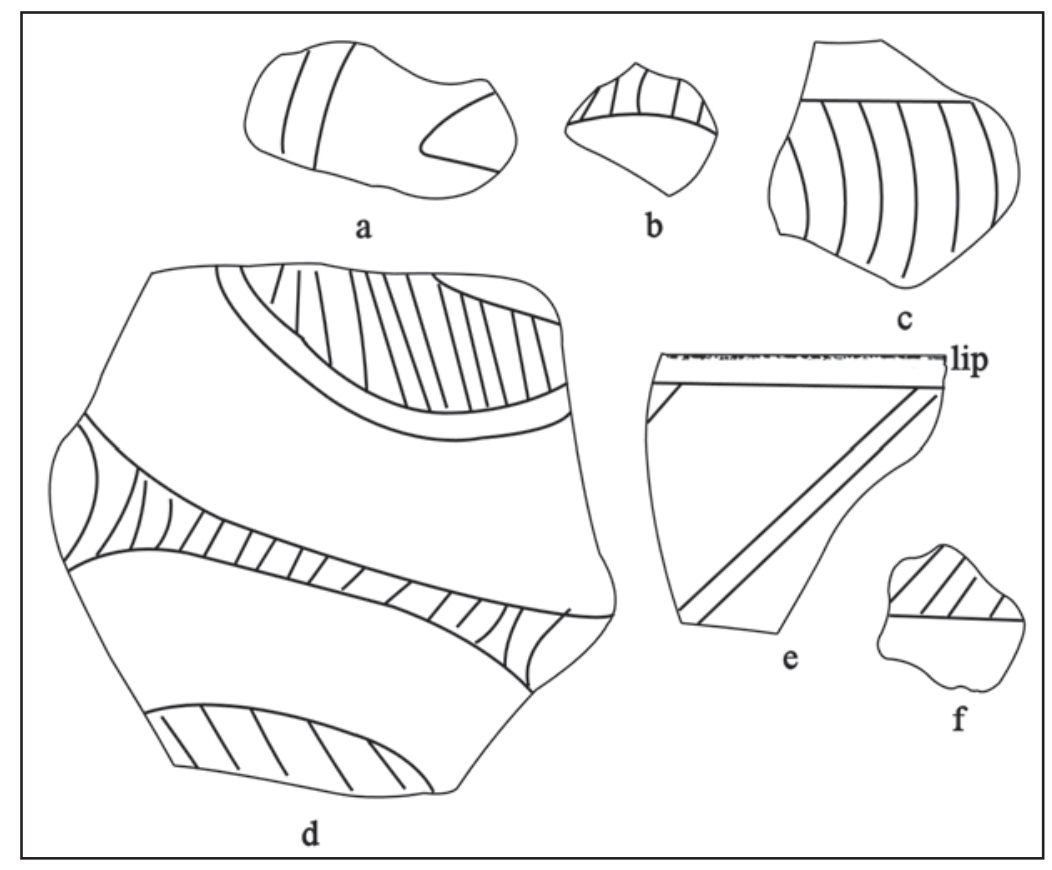

Figure 4. Selected decorative elements in the engraved ceramic wares from the Mike Myers site: a, ST 32, 0-20 cm bs; b, ST 15, 0-20 cm bs; c, ST 17, 20-40 cm bs; d, surface; e, Unit 3, 10-20 cm bs; f, Unit $2,30-40 \mathrm{~cm}$ bs. 
Table 7. Ceramic sherd assemblage comparisons of sites on Bowles Creek, including 41CE289 and 41CE20 (Source, Perttula 2017:Table 3).

\begin{tabular}{|c|c|c|c|c|c|}
\hline Site & $\%$ Grog & $\%$ Bone & $\mathrm{P} / \mathrm{DR}$ & $\mathrm{B} / \mathrm{Pl}$ & $\mathrm{B} / \mathrm{OWP} * *$ \\
\hline \multicolumn{6}{|c|}{ Allen phase (ca. post-A.D. 1680} \\
\hline \multicolumn{6}{|c|}{ Group I } \\
\hline$\overline{41 C E 293}$ & 98.1 & 5.6 & 0.12 & 7.50 & 5.70 \\
\hline $41 \mathrm{CE} 477$ & 95.8 & 4.2 & 0.18 & 4.73 & 13.0 \\
\hline 41CE474 & 97.1 & 2.9 & 0.30 & 3.08 & 9.25 \\
\hline \multicolumn{6}{|l|}{ Group II } \\
\hline $41 \mathrm{CE} 48$ & 84.2 & 27.7 & 0.31 & 2.43 & 5.48 \\
\hline $41 \mathrm{CE} 475$ & 91.2 & 9.2 & 0.34 & 2.55 & 11.3 \\
\hline 41CE20 & 85.7 & 14.3 & 0.40 & 2.07 & 5.0 \\
\hline $41 \mathrm{CE} 476$ & 91.2 & 9.2 & 0.45 & 1.77 & 7.0 \\
\hline 41CE291 & 97.4 & 2.6 & 0.30 & 1.94 & 1.84 \\
\hline \multicolumn{6}{|c|}{ Late Frankston phase (ca. A.D. 1560-1680) } \\
\hline \multicolumn{6}{|c|}{ Group III } \\
\hline 41CE19, & N/A & N/A & 0.82 & 0.78 & 1.90 \\
\hline \multicolumn{6}{|l|}{$\begin{array}{l}\text { Northern } \\
\text { part of site }\end{array}$} \\
\hline \multicolumn{6}{|c|}{ Possible Middle Caddo occupation, ca. A.D. 1300-1400 } \\
\hline \multicolumn{6}{|c|}{ Group IV } \\
\hline 41CE289 & 82.1 & 17.9 & 1.38 & 0.49 & 2.38 \\
\hline 41CE481 & $\mathbf{7 7 . 4}$ & 22.6 & 2.00 & 0.26 & 1.31 \\
\hline
\end{tabular}

$\mathrm{P} / \mathrm{DR}=$ plain to decorated sherd ratio; $\mathrm{B} / \mathrm{Pl}=$ brushed/plain sherd ratio; $\mathrm{B} / \mathrm{OWP}=$ brushed/other wet paste sherd ratio

\section{Woodland Period Ceramic Sherds}

Two early Woodland Tchefuncte ceramic sherds, one rim and one body sherd probably from the same vessel, have been identified in the ceramic sherd assemblage from the Mike Myers site. Both have been identified as Lake Borgne Incised (Rich Weinstein, November 8, 2016 personal communication; see also Brown 1998:25). Weinstein commented:

The jab-and-drag lines are very fine and extremely well done, but there is no question that they are jab-and-drag. There is no evidence of any grog in the paste, which is highly laminated in typical Tchefuncte fashion. Overall, excellent examples of Lake Borgne Incised.

Not sure if we want to assign a variety name to the sherds, given that there are only two of them and they are well removed geographically from most examples of Lake Borgne. However, the body sherd has a narrow band without jab-and-drag incising, but instead several evenly spaced individual punctations. This motif is reminiscent of several sherds from the Bayou Jasmine site (16SJB2). At Bayou Jasmine, the motif occurred on sherds of Orleans Punctated, which Chris Hays and I named Orleans Punctated, var. Jasmine (see Hays and Weinstein 1999:Fig. 8, d-f). This is the first time I've seen a similar decoration on Lake Borgne, although there may be other examples shown in some gray literature somewhere. It certainly would be interesting to see if any similar sherds are illustrated from other sites in NE Texas. If there are others in the region, then a new variety 
name may be appropriate. I did look at the report on the Resch site (41HS16) by Webb et al. (1969), which had a modest Tchefuncte component, but didn't see any illustrated examples of Lake Borgne. (Of course, the whole vessel of Tchefuncte Stamped, var. Resch is a classic from that site.)

For what it's worth, the var. Jasmine sherds all came from some of the deepest levels at Bayou Jasmine; levels dated to between cal 840 and 400 B.C. (Hays and Weinstein 1999:Table 1). In fact, the earliness of the variety is the main reason that we set it up as a new category in the hope that it would prove to be a good chronological marker for early Tchefuncte components. Although the same design is on a sherd of Lake Borgne Incised at 41CE481, and not Orleans Punctated, it still could represent a relatively early component.

Anyway, there you have it. Your sherds are definitely Lake Borgne Incised. There must be a Tchefuncte component at the site (perhaps early within the culture), or at least an occupation equivalent in time to the Early Woodland (Tchula) period that may have received at least one Tchefuncte trade vessel.

The Lake Borgne Incised sherds include a rim (ST 7, 20-40 cm bs) and a body (ST 9, $85 \mathrm{~cm}$ bs) sherd from a non-tempered vessel with a laminated paste (Figure $5 \mathrm{a}-\mathrm{b})$. The rim has a wide $(14 \mathrm{~mm})$ and convex lip with 14+ horizontal rows of small jab and drag punctations, as well as an incised-punctated decorative element on the rim itself. This includes a single horizontal incised lip part way down the rim and a diagonal-vertical incised zone filled with small circular punctations. The body sherd is $6.6 \mathrm{~mm}$ thick. It is decorated with one vertical row of circular punctations dividing at least 10 rows of small jab and drag punctations.

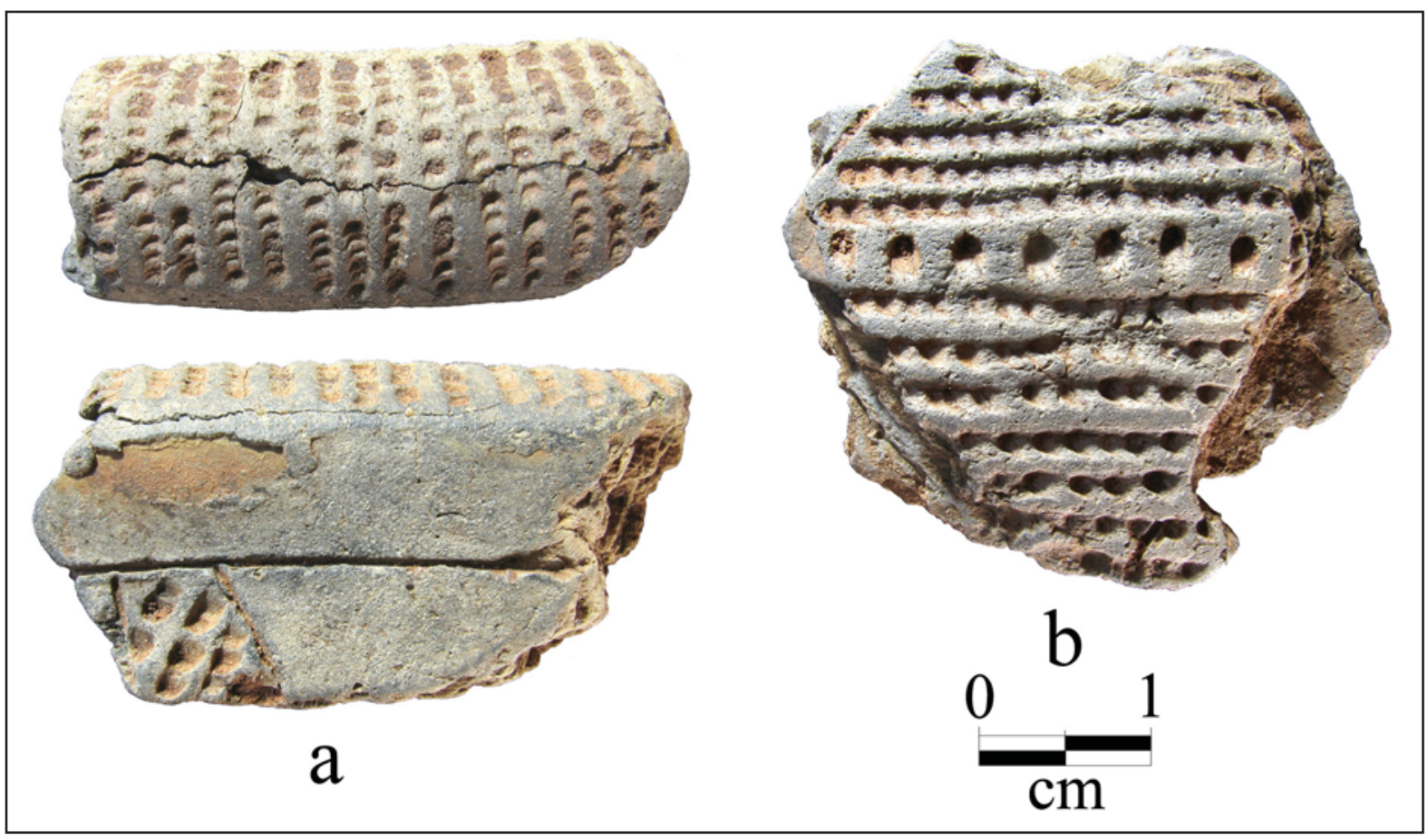

Figure 5. Lake Borgne Incised sherds from the Mike Myers site: a, ST 7, 20-40 cm bs; b, ST 9, $85 \mathrm{~cm}$ bs. 
The other identified Woodland period sherds at the Mike Myers site include a third non-tempered and laminated body sherd (ST 103, 0-20 cm bs), this one undecorated, and 14 Goose Creek Plain, var. unspecified sandy paste sherds. The sandy paste Goose Creek sherds were found between $20-60 \mathrm{~cm}$ bs in Units 1-3 ( $\mathrm{n}=9)$ and between $0-20 \mathrm{~cm}$ bs $(\mathrm{n}=1), 20-40 \mathrm{~cm}$ bs $(\mathrm{n}=2)$, and $60-80 \mathrm{~cm}$ bs $(\mathrm{n}=2)$ in three shovel tests (n=5, ST 13, ST 24, and ST 43) not far from Units 1-3 (see Figure 2b). The presence of both the decorated Tchefuncte ware and the plain sandy paste sherds suggests that the site was occupied by Mossy Grove culture peoples during the early part of the Woodland period, ca. 500-400 B.C. (see Story 1990; Ellis 2013).

\section{Arrow Points}

Five arrow points or arrow point fragments have been recovered during the archaeological investigations at the Mike Myers site (Table 8 and Figure 6), two from the surface collections, one from $10-20 \mathrm{~cm}$ bs in Unit 1, and two others from $40-60 \mathrm{~cm}$ bs in two different shovel tests. The identified types include Steiner (Figure 6a), a Late Woodland type in East Texas (Shafer and Walters 2010), Bonham (Figure 6b), and Perdiz (Figure 6c) (see Turner et al. 2011). The latter two points are found in Middle Caddo period contexts in the region, although Perdiz points continued to be manufactured by Caddo knappers after ca. A.D. 1680. In any case, they indicate at least two periods of use of the site by ancestral Caddo peoples.

Table 8. Arrow points from the Mike Myers site (41CE481).

\begin{tabular}{|c|c|c|c|c|c|c|}
\hline $\begin{array}{l}\text { Provenience } \\
(\mathrm{cm} \mathrm{bs})\end{array}$ & Description & Raw material & $\begin{array}{l}\mathrm{L} \\
(\mathrm{mm})\end{array}$ & $\begin{array}{l}\text { W } \\
(\mathrm{mm})\end{array}$ & $\begin{array}{l}\text { SW } \\
(\mathrm{mm})\end{array}$ & $\begin{array}{l}\text { Th } \\
(\mathrm{mm})\end{array}$ \\
\hline Surface & Bonham type & Quartzite & $13.0+$ & 12.4 & 4.2 & 2.5 \\
\hline Surface & cf. Steiner & brown chert & N/A & & & \\
\hline Unit $1,10-20$ & blade frag. & dark gray chert & N/A & & & \\
\hline ST $3,40-60$ & tip & Petrified wood & - & - & - & 3.2 \\
\hline ST $41,40-60$ & Perdiz & Quartzite & 15.2 & 14.0 & 4.0 & 3.1 \\
\hline
\end{tabular}

L=length; W=width; SW=stem width; Th=thickness

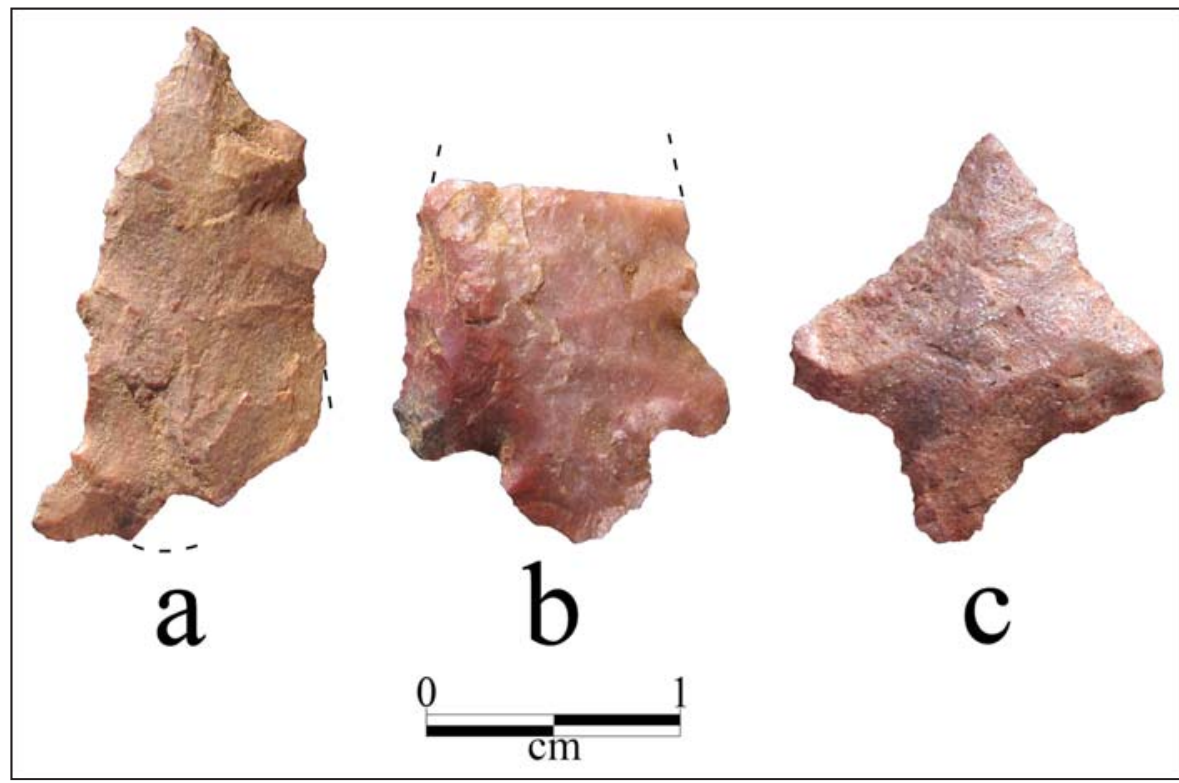

Figure 6. Arrow points from the Mike Myers site: a, cf. Steiner; b, Bonham; c, Perdiz. 
Three of the arrow points (60 percent) are made from local quartzite or petrified wood. The cf. Steiner point is made from a likely local brown chert, while the blade fragment is made from a non-local dark gray chert.

\section{Dart Points}

The eight dart points recovered from the Mike Myers site are found throughout the archaeological deposits, but are concentrated between $40-60 \mathrm{~cm}$ bs (Table 9). They include one Late Archaic type-a Yarbrough point from ST 37 (Figure 7a) - and five of Woodland period age in East Texas sites, namely two Kent (Figure 7b-c), including one found between 80-93 cm bs, one Neches type (Figure 7d) point, and two Gary points (Figure 7e). These Woodland period points are associated with the Mossy Grove occupation marked by Tchefuncte ceramic sherds and Goose Creek Plain sandy paste ceramic sherds. There are also a distal fragment and a tip/blade fragment to two other dart points in the assemblage; both of these were recovered between $40-60 \mathrm{~cm}$ bs.

Table 9. Dart points from the Mike Myers site (41CE481).

\begin{tabular}{|c|c|c|c|c|c|c|}
\hline $\begin{array}{l}\text { Provenience } \\
\text { (cm bs) }\end{array}$ & Description & Raw material & $\begin{array}{l}\mathrm{L} \\
(\mathrm{mm})\end{array}$ & $\begin{array}{l}\mathrm{W} \\
(\mathrm{mm})\end{array}$ & $\begin{array}{l}\mathrm{SW} \\
(\mathrm{mm})\end{array}$ & $\begin{array}{l}\text { Th } \\
(\mathrm{mm})\end{array}$ \\
\hline Unit $1,0-10$ & Gary & Banded chert & 34.1 & 19.9 & 13.9 & 4.9 \\
\hline ST $24,20-40$ & Neches type & Gray chert & - & - & 12.0 & 5.9 \\
\hline ST $9,40-60$ & Gary type & Quartzitic sandstone & - & - & 10.0 & 5.9 \\
\hline ST $13,40-60$ & distal frag. & $\begin{array}{l}\text { Grayish-yellow } \\
\text { chert }\end{array}$ & - & - & - & - \\
\hline ST $31,40-60$ & Kent type & Petrified wood & 47.0 & 23.0 & 14.8 & 11.5 \\
\hline ST $32,40-60$ & tip/blade & Petrified wood & - & - & - & 4.9 \\
\hline ST $37,40-60$ & Yarbrough & $\begin{array}{l}\text { Yellowish-gray } \\
\text { chert }\end{array}$ & 57.8 & 24.0 & 17.1 & 9.6 \\
\hline ST 9, 80-93 & Kent type & Petrified wood & 52.9 & 21.0 & 15.9 & 6.7 \\
\hline
\end{tabular}

L=length; $\mathrm{W}=$ width; $\mathrm{SW}=$ stem width; Th=thickness

Half of the dart points are made from cherts of various colors, likely representing a combination of both local and non-local raw material sources. The remainder are made from petrified wood (37.5 percent), a local raw material source, and a local coarse-grained quartzitic sandstone (see Table 9). 


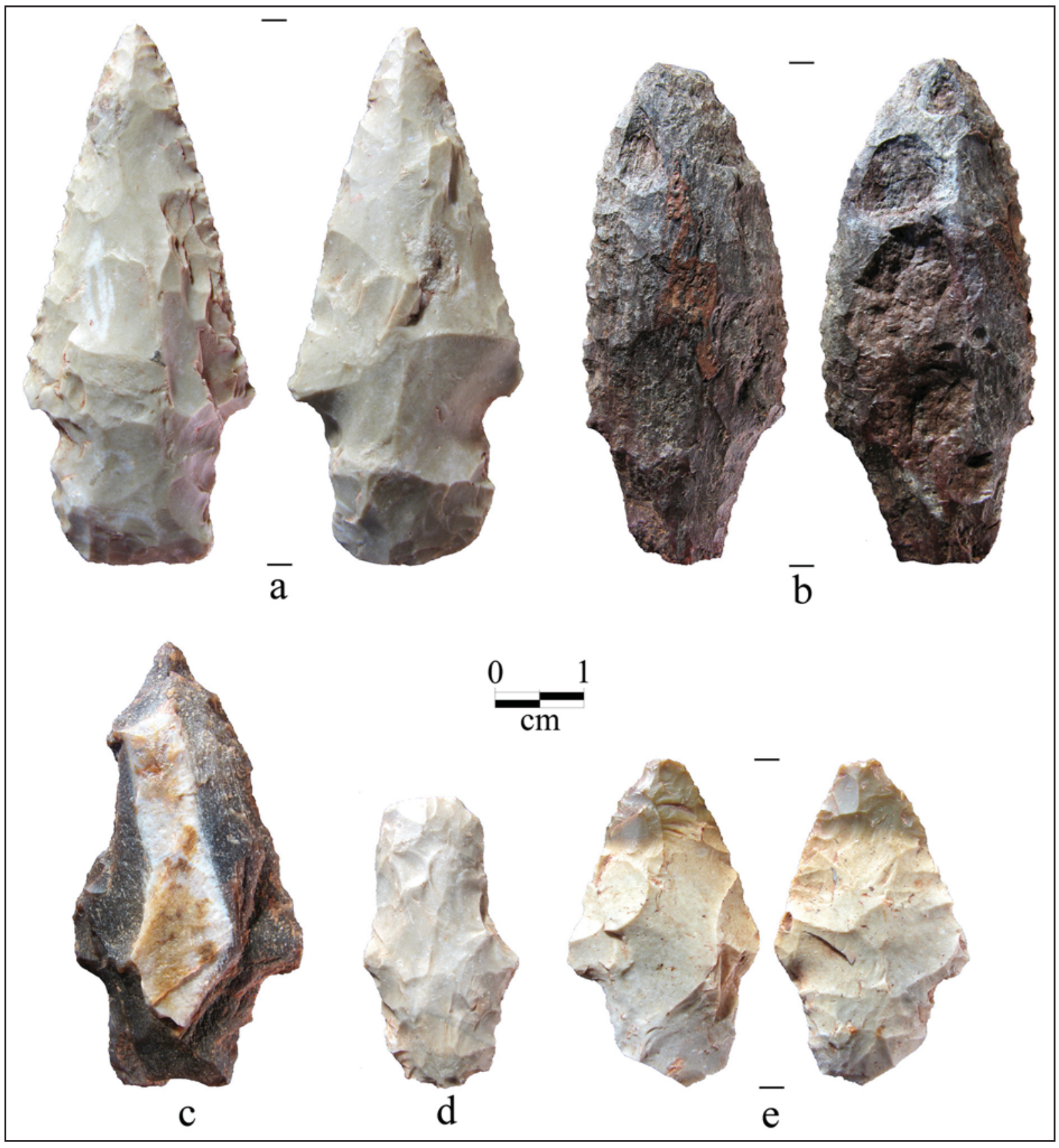

Figure 7. Dart points from the Mike Myers site: a, Yarbrough; b-c, Kent; d, Neches; e, Gary. 


\section{Bifaces}

The four recovered bifaces represent fragments of chipped stone tool production during the occupation of the Mike Myers site, probably the attempted production of dart points or knives. All four of the bifaces are on local petrified wood and quartzitic sandstone raw materials (Table 10).

Table 10. Bifaces from the Mike Myers site (41CE481).

\begin{tabular}{lllc}
\hline $\begin{array}{l}\text { Provenience } \\
(\mathrm{cm} \mathrm{bs})\end{array}$ & Description & Raw Material & Thickness (mm) \\
\hline ST 32, 0-20 & Biface preform & Petrified wood & 5.0 \\
ST 34, 0-20 & Biface fragment & Petrified wood & 9.7 \\
ST 102, 20-40 & Biface fragment & Petrified wood & 6.7 \\
ST 32, 40-60 & Biface preform & Quartzitic sandstone & 9.6 \\
\hline
\end{tabular}

\section{Flake Tools}

All four of the flake tools in the assemblage are made from chert (Table 11). They are expedient artifacts consisting of cortical or non-cortical flakes "that were used without further modification but which possessed attributes such as suitable edges for which they were selected" (Shafer and Walters 2010:138). Each of the expedient flake tools has only one modified or retouched edge.

Table 11. Flake tools from the Mike Myers site (41CE481).

\begin{tabular}{lll}
\hline $\begin{array}{l}\text { Provenience } \\
(\mathrm{cm} \text { bs })\end{array}$ & Description & Raw Material/Cortex \\
\hline Surface & expedient, unifacial & Gray chert, non-cortical \\
Unit 2, 10-20 & expedient, unifacial & Reddish-brown chert, non-cortical \\
ST 30, 20-40 & expedient, unifacial & Grayish-brown chert, cortical-smoothed \\
ST 36, 60-85 & expedient, unifacial & Gray chert, non-cortical \\
\hline
\end{tabular}

\section{Lithic Debris and Cores}

The lithic debris and cores are from a wide variety of raw materials of both local and non-local derivation, including chalcedony, ferruginous sandstone, jasper, Manning Fused Glass (see Brown 1976), novaculite, petrified wood, quartzite, a coarse white quartzitic sandstone from the local Reklaw Formation (Stephenson 1952), and cherts of many different colors (Table 12). The most common lithic raw materials represented in the lithic debris/cores assemblage from the Mike Myers site are gray chert (17.2 percent), light gray chert (15.4 percent), quartzite (13.0 percent), and petrified wood (11.6 percent). Overall, 70.5 percent of the lithic debris/cores are different colors of chert. 
Table 12. Lithic debris and cores from the Mike Myers site (41CE481).

\begin{tabular}{|c|c|c|}
\hline Raw Material & $\mathrm{N}$ & Percent cortical \\
\hline Chalcedony & 7 & 28.7 \\
\hline Ferruginous sandstone & 1 & - \\
\hline Jasper & 1 & - \\
\hline Manning Fused Glass & 4 & - \\
\hline Novaculite & 1 & - \\
\hline Petrified wood & 76 & 52.6 \\
\hline Quartzite & 85 & 43.5 \\
\hline Quartzitic sandstone & 19 & 5.3 \\
\hline black chert & 3 & - \\
\hline brown chert & 14 & 42.9 \\
\hline dark brown chert & 3 & 100.0 \\
\hline very dark brown chert & 1 & 100.0 \\
\hline brownish-gray chert & 33 & 36.4 \\
\hline brownish-red chert & 4 & 25.0 \\
\hline bluish-gray chert & 8 & 25.0 \\
\hline light grayish-brown chert & 1 & - \\
\hline light gray chert & 101 & 5.0 \\
\hline gray chert & 113 & 9.7 \\
\hline gray-dark gray chert & 1 & - \\
\hline dark gray chert & 27 & 18.5 \\
\hline very dark gray chert & 31 & - \\
\hline dark grayish-brown chert & 1 & - \\
\hline very dark grayish-brown chert & 2 & - \\
\hline grayish-brown chert & 24 & 25.0 \\
\hline grayish-red chert & 4 & 75.0 \\
\hline grayish-yellow chert & 1 & - \\
\hline dark red chert & 2 & 50.0 \\
\hline light red chert & 1 & - \\
\hline red chert & 13 & 69.2 \\
\hline reddish-brown chert & 6 & 66.7 \\
\hline reddish-gray chert & 9 & 44.4 \\
\hline
\end{tabular}


Table 12. Lithic debris and cores from the Mike Myers site (41CE481), cont.

\begin{tabular}{lll}
\hline Raw Material & N & Percent cortical \\
\hline yellow chert & 6 & 33.3 \\
yellowish-brown chert & 5 & 40.0 \\
yellowish-gray chert & 26 & 23.1 \\
light yellowish-gray & 1 & - \\
white chert & 17 & - \\
white-black chert & 1 & - \\
white-dark gray chert & 1 & - \\
white-very dark gray chert & 2 & 24.9 \\
\hline Totals & 656 & \\
\hline
\end{tabular}

Almost 25 percent of the lithic debris has cortical remnants, almost all with a smooth cortex, suggesting that they were primarily detached from stream-rolled pebbles in gravel beds, mostly available in nearby Neches River gravel sources. Based on the proportions of cortex in the different raw materials, indicating that lithic raw materials in the form of cortex-covered pebbles or cobbles were brought to the site for reduction, the following raw materials are suggested to have been procured from locally available resources:
Chalcedony
Petrified wood
Quartzite
brown chert
dark brown chert
brownish-gray chert
grayish-red chert
dark red chert
red chert
reddish-brown chert
reddish-gray chert
yellow chert
yellowish-brown chert

These raw materials account for 40 percent of the lithic debris in the Mike Myers assemblage. It is also known that the coarse-grained white quartzitic sandstone is a local raw material (see Stephenson 1952); this material accounts for another 2.9 percent of the lithic debris assemblage. Manning Fused Glass, represented by only 0.6 percent of the lithic debris, is a regionally available raw material present in Manning Formation sources about 70-80 km south of the Bowles Creek valley (Brown 1976:Figure 3).

Other raw materials in the lithic debris are known or suggested to be from non-local source areas, including:

Jasper

Novaculite

black chert

very dark gray chert

very dark grayish-brown chert 
bluish-gray chert

light gray chert

gray chert

white chert

white-black chert

white-very dark gray chert

The jasper and novaculite likely originated in Red River gravel sources well to the north of the Mike Myers site, but they only account for 0.3 percent of the lithic debris sample. The other raw materials are chert, primarily small non-cortical pieces from resharpening and final tool manufacture knapping, and likely originated in Central Texas source areas. These cherts comprise 42 percent of the lithic debris assemblage, and suggests that the ancestral Caddo occupants of the site had a catchment area that included areas well to the west of the Neches River basin, namely the "area encompassed by the geographic extent of hunting and gathering trips from a particular site" (Shafer and Walters 2010:140).

\section{Fire-cracked Rock}

The one piece of fire-cracked rock in the artifact assemblage came from Unit 3, 20-30 cm bs. It is a small piece of heat-fractured quartzite. The rarity of fire-cracked rock suggests that the occupants of the Mike Myers site did not rely on hot rock cooking for the cooking of plant and animal foods.

\section{Animal Bones}

Burned animal bones are relatively abundant in the site's archaeological deposits, as 196 pieces were collected from both shovel tests and the excavation of Units 1-3 (see Table 2); the faunal assemblage is very fragmented, and it has not yet been studied by a faunal analyst. The mean density of animal bone in the positive shovel tests is 2.55 per positive shovel test, or ca. 20.4 pieces per square meter; only 21 of the 45 positive shovel tests contain burned animal bone, however. In Units 1-3, the mean density is 27.0 pieces per square meter.

\section{Wood Charcoal and Charred Nutshells}

Only 12 pieces of wood charcoal and 22 pieces of charred nutshells have been recovered in the archaeological investigations at the Mike Myers site. In shovel tests, the density of wood charcoal is only 0.22 pieces per positive shovel test, or ca. 1.76 pieces per square meter; only six shovel tests ( 13 percent of the positive shovel tests) had wood charcoal pieces. In Units 1-3, the mean density of wood charcoal is only 0.67 pieces per square meter. Charred nutshell is present in nine (20 percent) positive shovel tests, at a density of 0.267 pieces per positive shovel test, or ca. 2.1 pieces per square meter. The mean density of charred nutshell pieces in Units 1-3 is slightly higher at 3.3 pieces per square meter. Two or three samples of charred nutshells from different depths in the deposit are to be submitted for radiocarbon dating in the near future, primarily to establish the ages and occupation spans of the Woodland period use of the Mike Myers site.

\section{Summary and Synthesis of the Findings}

The Mike Myers site (41CE481) is a multi-component archaeological site in the Bowles Creek valley in the Neches River basin in the East Texas Pineywoods. Based on the recovery of plain and decorated ceramic sherds, dart points, and arrow points in the archaeological deposits, the recognized components include Late Archaic (marked by a Yarbrough point), early and late Woodland (marked by a Steiner arrow point), the Middle Caddo period, and during Historic Caddo period times (marked by sherds of Lindsey Grooved and Keno Trailed), with the early Woodland and Middle Caddo components representing the principal periods of use by ancestral Caddo peoples. 
The archaeological investigations at the site included a surface collection, 45 positive shovel tests, and a $3 \times 1 \mathrm{~m}$ unit across a known site area of about 2 acres of an upland landform. The shovel tests and units indicate that the archaeological deposits range from ca. $20-100 \mathrm{~cm}$ in thickness, and the deeper deposits (greater than $60 \mathrm{~cm}$ bs) are concentrated in a $60 \times 15 \mathrm{~m}$ area in the southern part of the site. Although no features have been identified in this area during the present investigations, the highest densities of plain and decorated ceramic sherds, animal bones, charred nutshells, and lithic debris occur in this area. These materials are found throughout the archaeological deposits, but are concentrated between $0-60 \mathrm{~cm}$ bs in the shovel testing and $20-50 \mathrm{~cm}$ bs in Units 1-3. It is likely that there are spatially overlapping Woodland and Middle Caddo components at the site, but likely not vertically discrete deposits given the site's location on an upland landform.

The early Woodland period component at the Mike Myers site is distinctive because two sherds of Lake Borgne Incised, a Tchefuncte culture ceramic ware, have been found in the shovel testing at the site; indeed, their discovery was the impetus for the excavation of many more shovel tests and Units 1-3 here to try to determine the context of the sherds and their possible age (through the recovery of charred nutshells or unburned animal bone). Tchefuncte ceramics are very rarely discovered in East Texas Woodland period sites, and those at the Mike Myers site likely represent trade and transport of a Tchefuncte vessel from the Texas Gulf Coast (Aten and Bollich 2011) or the lower Mississippi River valley (Hays and Weinstein 2010). Artifacts likely to be associated with the Tchefuncte ceramics at the site include sandy paste Goose Creek Plain, var. unspecified ceramic sherds, the majority of the dart points, and much of the burned animal bones and charred nutshells. The site may have been used by Mossy Grove culture peoples on several occasions during the early Woodland period, from perhaps as early as ca. 500 B.C. to ca. A.D. 1.

Over a millennia later, the Mike Myers site was occupied again by Caddo peoples during the Middle Caddo period (ca. A.D. 1200-1400). This was a fairly substantial occupation, probably an occupation consisting of one to several family/farm compounds on the upland landform. These compounds probably consisted of residential structures, ramadas/granaries, outdoor activity areas, and localized trash deposits. The most common artifact type recovered in this component at the site consists of plain, utility, and fine ware ceramic sherds from grog-tempered, grog-bone-tempered, and bone-tempered vessels. Many of the utility wares have brushed decorative elements, as well as sherds with incised and punctated decorations, and about 26 percent of the decorated sherds are from engraved or trailed vessels. The distinctive ceramic metrics of the assemblage (see Table 7), along with the absence of sherds of either Poynor Engraved or Patton Engraved, points to the ancestral Caddo occupation having taken place sometime during the Middle Caddo period. In this part of the Bowles Creek basin (Perttula et al. 2016), all other identified and recorded sites date to post-A.D. 1680 Historic Caddo times.

Further archaeological investigations are warranted at the Mike Myers site, primarily to identify archaeological features and concentrated as well as discrete archaeological deposits associated with the early Woodland and Middle Caddo period occupations. The identification and excavation of archaeological features, along with obtaining a number of radiocarbon dates from controlled contexts, will go a long way in helping to unravel the character of the two occupations - as well as their spatial and vertical interrelationships - particularly the nature of the settlements during these periods but also the nature of the material culture remains and subsistence debris that characterize the two different occupations. 


\section{Acknowledgments}

First, we thank the landowner, Mike Myers, for permission to work at the site on his property. We also thank Tom Middlebrook, Morris Jackson, and Ron Coleman for their help in the excavation of Unit 1, and we appreciate the help of Mark Walters in examining the profiles and floor of Units 1-3 and in completing the excavation of several shovel tests at the site. Thanks also to Rich Weinstein (Coastal Environments, Inc.) for examining the Lake Borgne Incised sherds recovered in the site shovel testing. Lance Trask prepared the figures for this article.

\section{References Cited}

Aten, L. E.

1983 Indians of the Upper Texas Coast. Academic Press, New York.

Aten, L. E. and C. N. Bollich

2011 Early Ceramic Sites of the Sabine Lake Area, Coastal Texas and Louisiana. Studies in Archeology 43. Texas Archeological Research Laboratory, The University of Texas at Austin.

Brown, I. W.

1998 Decorated Pottery of the Lower Mississippi Valley: A Sorting Manual. Mississippi Archaeological Association and Mississippi Department of Archives and History, Jackson.

Brown, K. M.

1976 Fused Volcanic Glass from the Manning Formation. Bulletin of the Texas Archeological Society 47:189-207.

Ellis, L. W.

2013 Woodland Ceramics in East Texas and a Case Study of Mill Creek Culture Ceramics. Bulletin of the Texas Archeological Society 84:137-180.

Hays, C. T. and R. A. Weinstein

1999 Perspectives on Tchefuncte Cultural Chronology: A View from the Bayou Jasmine Site, St. John the Baptist Parish, Louisiana. Louisiana Archaeology 23:49-89.

2010 Tchefuncte and Early Woodland. In Archaeology of Louisiana, edited by M. A. Rees, pp. 97-119. Louisiana State University Press, Baton Rouge.

Mowery, L. C. and H. Oakes

1959 Soil Survey of Cherokee County, Texas. United States Department of Agriculture, Government Printing Office, Washington, D.C.

Perttula, T. K.

2017 Analysis of Ancestral Caddo Ceramic Assemblages from the Gas Line Site (41CE63) and 41CE289, Neches River Basin, Cherokee County, Texas. Journal of Northeast Texas Archaeology 72:43-49.

Perttula, T. K., K. Stingley, and M. Walters

2016 Historic Caddo Archaeological Sites in Cherokee County, Texas. Journal of Northeast Texas Archaeology 65:1-24.

Shafer, H. and M. Walters

2010 The Browning Site (41SM195A) Lithics: Considering Patterns of Identity and Interaction Through Lithic Analysis. Bulletin of the Texas Archeological Society 81:127-151.

Stephenson, L. W.

1952 Probable Reklaw Age of a Ferruginous Conglomerate in Eastern Texas. Geological Survey Professional Paper 243-C. U.S. Government Printing Office, Washington, D.C. 
Story, D. A.

1990 Cultural History of the Native Americans. In The Archeology and Bioarcheology of the Gulf Coastal Plain, by D. A. Story, J. A Guy, B. A. Burnett, M. D. Freeman, J. C. Rose, D. G. Steele, B. W. Olive, and K. J. Reinhard, pp. 163-366. Research Series No. 38. 2 Vols. Arkansas Archeological Survey, Fayetteville.

Turner, E. S., T. R. Hester, and R. L. McReynolds

2011 Stone Artifacts of Texas Indians. Taylor Trade Publishing, Lanham, Maryland.

Webb, C. H., F. E. Murphey, W. G. Ellis, and H. R. Green

1969 The Resch Site, 41HS16, Harrison County, Texas. Bulletin of the Texas Archeological Society 40:3106. 


\section{Appendix 1, February 2017 Archaeological Investigations at the Mike Myers Site (41CE481)}

Additional shovel tests were excavated at the Mike Myers site in February 2017 to clarify its extent and character on the southern part of the upland landform (Figure A1-1); a small surface collection of artifacts was also obtained at that time. All 15 of the shovel tests contained prehistoric artifacts in relatively deep reddish-brown sandy loam sediments (Table A1-1), and they extend the boundary of the site at least $40 \mathrm{~m}$ to the south (and thus it extends at least $100 \mathrm{~m}$ to the north and south); the total extent of the site to the south, east, and west has not been determined, however, although it is at leest $60 \mathrm{~m}$ in size east-west.

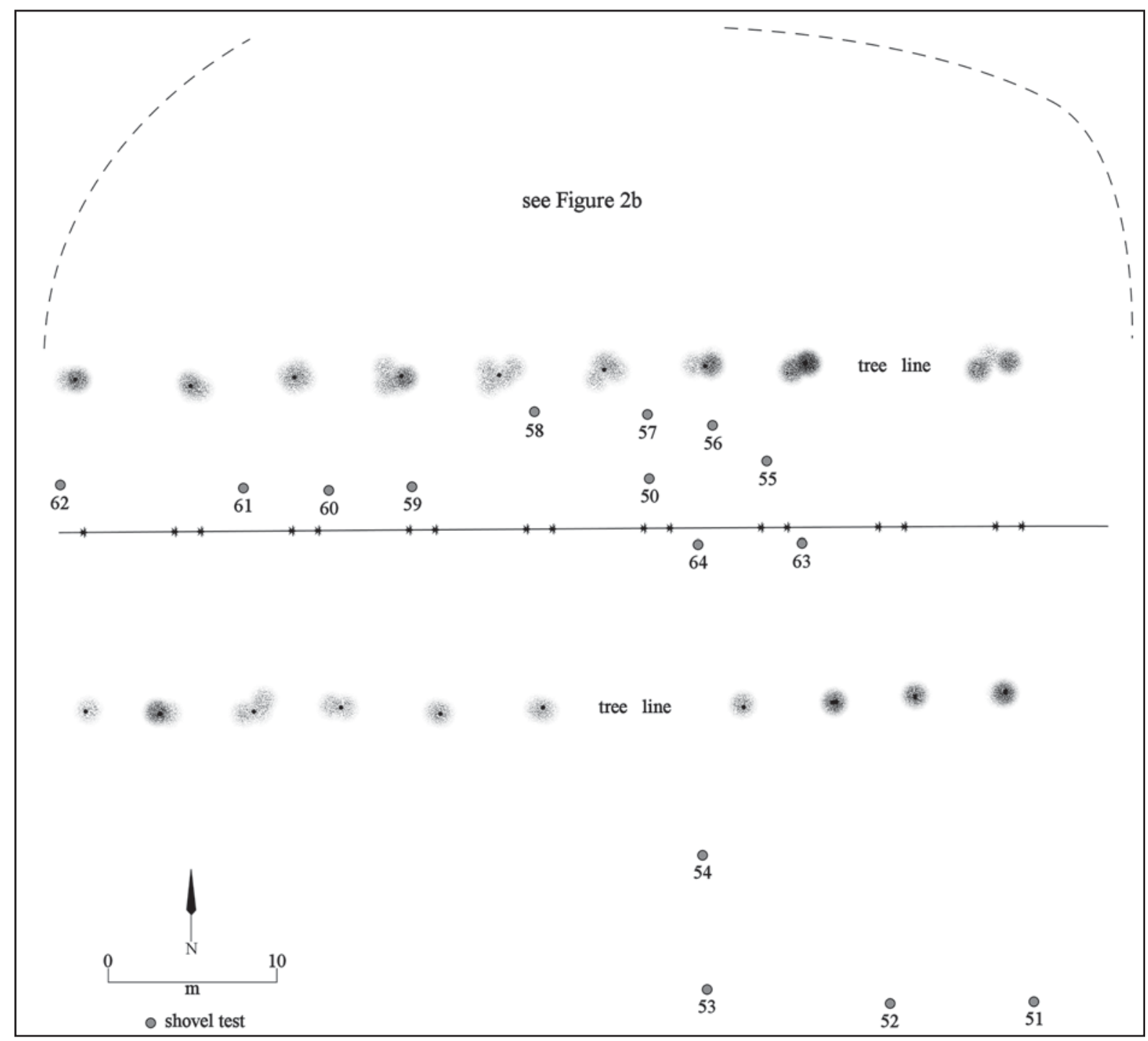

Figure A1-1. Location of ST 50-64 on the southern part of the landform and south of 2016 archaeological investigations. 
Table A1-1. Descriptions of the sediments in shovel tests at the Mike Myers site (41CE481).

\begin{tabular}{ll}
\hline ST No. & Description \\
\hline 50 & $0-92 \mathrm{~cm}$, reddish-brown sandy loam; $92 \mathrm{~cm}+$, reddish-brown sandy clay \\
51 & $0-87 \mathrm{~cm}$, reddish-brown sandy loam; $87 \mathrm{~cm}+$, reddish-brown sandy clay \\
52 & $0-78 \mathrm{~cm}$, reddish-brown sandy loam; $78 \mathrm{~cm}+$, reddish-brown sandy clay \\
53 & $0-82 \mathrm{~cm}$, reddish-brown sandy loam; $82 \mathrm{~cm}+$, reddish-brown sandy clay \\
54 & $0-76 \mathrm{~cm}$, reddish-brown sandy loam; $76 \mathrm{~cm}+$, reddish-brown sandy clay \\
55 & $0-92 \mathrm{~cm}$, reddish-brown sandy loam; $92 \mathrm{~cm}+$, reddish-brown sandy clay \\
56 & $0-86 \mathrm{~cm}$, reddish-brown sandy loam; $86 \mathrm{~cm}+$, reddish-brown sandy clay \\
57 & $0-87 \mathrm{~cm}$, reddish-brown sandy loam; $87 \mathrm{~cm}+$, reddish-brown sandy clay \\
58 & $0-88 \mathrm{~cm}$, reddish-brown sandy loam; $88 \mathrm{~cm}+$, reddish-brown sandy clay \\
59 & $0-90 \mathrm{~cm}$, reddish-brown sandy loam; $90 \mathrm{~cm}+$, reddish-brown sandy clay \\
60 & $0-100 \mathrm{~cm}$, reddish-brown sandy loam; $100 \mathrm{~cm}+$, reddish-brown sandy clay \\
61 & $0-100 \mathrm{~cm}$, reddish-brown sandy loam; $100 \mathrm{~cm}+$, reddish-brown sandy clay \\
62 & $0-93 \mathrm{~cm}$, reddish-brown sandy loam; $93 \mathrm{~cm}+$, reddish-brown sandy clay \\
63 & $0-90 \mathrm{~cm}$, reddish-brown sandy loam; $90 \mathrm{~cm}+$, reddish-brown sandy clay \\
64 & $0-100 \mathrm{~cm}$, reddish-brown sandy loam; $100 \mathrm{~cm}+$, reddish-brown sandy clay \\
\hline
\end{tabular}

The mean density of artifacts in ST 50-64 is 11.5 per positive shovel test (Table A1-2), about 30 percent less than in the shovel tests in the northern part of the site; this is ca. 92 artifacts per square meter of archaeological deposits. The highest density of artifacts is in ST 59 ( $\mathrm{n}=36$ or ca. 288 artifacts per square meter) at the fence line, but ST 51, ST 55, and ST 56 have densities that range from 14-17 artifacts, or ca. 112-136 artifacts per square meter; ST 559 also has more than 80 percent of the recovered animal bone in this group of shovel tests, and may mark the location of a feature or small midden deposit. ST 51 is at the southeastern limits of the shovel testing work (see Figure A1-1), while ST 55 and ST 56 are along the fence line, about 6-8 $\mathrm{m}$ south of the shovel tests in the northern part of the site.

Table A1-2. Distribution of Artifacts in ST 50-64 at the Mike Myers site (41CE481).

\begin{tabular}{|c|c|c|c|c|c|c|c|c|c|c|}
\hline Prov. & PS & $\mathrm{DS}$ & AP & $\mathrm{DP}$ & Bif & FT & LD & $\mathrm{AB}$ & $\begin{array}{l}\mathrm{WC} / \\
\mathrm{NS}\end{array}$ & $\mathrm{N}$ \\
\hline ST 50 & 3 & 1 & - & - & - & - & 4 & - & $3 /-$ & 11 \\
\hline ST 51 & 5 & 1 & - & - & - & 1 & 9 & - & $-/-$ & 16 \\
\hline ST 52 & 3 & - & - & 1 & - & - & 6 & - & $-/-$ & 10 \\
\hline ST 53 & 2 & - & - & - & - & - & 6 & - & $-/-$ & 8 \\
\hline ST 54 & - & - & - & - & - & 1 & 2 & - & $-/-$ & $4 *$ \\
\hline ST 55 & 2 & 2 & - & - & - & - & 10 & - & $-/-$ & 14 \\
\hline ST 56 & 2 & 5 & - & 2 & - & - & 8 & - & $-/-$ & 17 \\
\hline ST 57 & 5 & - & - & - & - & - & 1 & 2 & $-/-$ & 8 \\
\hline ST 58 & 1 & - & - & - & - & - & 3 & - & $-1-$ & 4 \\
\hline ST 59 & 11 & 3 & - & - & - & - & 6 & 16 & $-/-$ & 36 \\
\hline ST 60 & 2 & - & 1 & - & - & - & 7 & - & $-/-$ & 10 \\
\hline ST 61 & 7 & 3 & - & - & - & - & 1 & - & $-/-$ & 11 \\
\hline ST 62 & 2 & - & - & - & - & 1 & 8 & - & $-/-$ & 11 \\
\hline ST 63 & 4 & 1 & - & - & - & - & 2 & 1 & $-/-$ & 8 \\
\hline ST 64 & 1 & - & - & - & - & - & 3 & - & $-/-$ & 4 \\
\hline Totals & 50 & 16 & 1 & 3 & - & 3 & 76 & 19 & $3 /-$ & 172 \\
\hline
\end{tabular}

*includes a nutting stone from $20-40 \mathrm{~cm}$ bs 
In this set of shovel tests at the Mike Myers site, the artifacts are concentrated between $0-80 \mathrm{~cm} \mathrm{bs}$, in deeper sandy loam deposits, with the highest densities between $40-80 \mathrm{~cm}$ bs (Table A1-3). Plain and decorated sherds are found mainly between $0-60 \mathrm{~cm}$ bs, and are primarily from ancestral Caddo use of the site, while dart points, flake tools, lithic debris, and animal bones are from a deeper component that likely occurred before the Caddo occupation, probably in the early Woodland period based on the kinds of dart points previously found at the site as well as the recovery of Woodland period Tchefuncte and Goose Creek Plain ceramic wares.

Table A1-3. Distribution of artifacts by depth in ST 50-64 at the Mike Myers site (41CE481).

\begin{tabular}{lllllll}
\hline Artifact Category & $0-20$ & $20-40$ & $\begin{array}{l}40-60 \\
\text { cm bs }\end{array}$ & $60-80$ & $80-100$ & N \\
\hline PS & 17 & 15 & 15 & 1 & 2 & 50 \\
DS & 7 & 8 & 1 & - & - & 16 \\
AP & - & - & 1 & - & - & 1 \\
DP & - & - & 1 & 2 & - & 3 \\
GS & - & 1 & - & - & - & 3 \\
FT & 1 & - & - & 1 & 1 & 76 \\
LD & - & 12 & 28 & 21 & 6 & 19 \\
AB & - & - & 1 & 18 & - & 3 \\
WC & 34 & 36 & 50 & 43 & 9 & 172 \\
\hline Totals & & & - & - & 9 \\
\hline
\end{tabular}

$\mathrm{PS}=$ plain sherd; $\mathrm{DS}=$ decorated sherd; $\mathrm{AP}=$ arrow point; $\mathrm{DP}=$ dart point; $\mathrm{GS}=$ ground stone tool; $\mathrm{FT}=$ flake tool; $\mathrm{LD}=$ lithic debris; $\mathrm{AB}=$ animal bone; $\mathrm{WC}=$ wood charcoal

Including the 2017 surface collection, the February 2017 investigations at the Mike Myers site recovered 94 plain or decorated sherds. The plain to decorated sherd ratio (P/DR) in this assemblage is 3.09 ( $\mathrm{n}=71$ plain sherds and 23 decorated sherds). The overall $\mathrm{P} / \mathrm{DR}$ for the entire site assemblage $(\mathrm{n}=431$ sherds) is 2.75 .

In the 2017 sherd assemblage, abut 81 percent of the sherds are from vessels tempered only with grog (Table A1-4); in the previously discussed assemblage, 77.4 percent of the sherds were from grogtempered vessels. About 13 percent of the sherds have bone temper, either as the sole temper or in conjunction with either grog and/or hematite. Almost 10 percent have crushed pieces of hematite added as temper inclusions.

Table A1-4. Ceramic Wares from the 2017 investigations at the Mike Myers site (41CE481).

\begin{tabular}{lcccccc}
\hline Ware & \multicolumn{5}{c}{ Temper } & N \\
& G & B & G-B & G-H & G-B-H & 71 \\
\hline Plain & 56 & 3 & 5 & 4 & 3 & 20 \\
Utility & 18 & - & 1 & 1 & - & 3 \\
Fine & 2 & - & - & 1 & - & 94 \\
\hline Totals & 76 & 3 & 6 & 6 & 3 & 94 \\
\hline
\end{tabular}

$\mathrm{G}=$ grog; $\mathrm{B}=$ bone; $\mathrm{G}-\mathrm{B}=$ grog-bone; $\mathrm{G}-\mathrm{H}=$ grog-hematite; $\mathrm{G}-\mathrm{B}-\mathrm{H}=$ grog-bone-hematite 
None of the sherds recovered in the 2017 investigations appear to be from Woodland period vessels with either a laminated paste (i.e., Tchefuncte wares) or a sandy paste (i.e., Goose Creek Plain); such sherds comprised about 6 percent of the sherd sample from the northern part of the site. Instead, all of the sherds from the southern part of the site appear to be the product of one or more ancestral Caddo components.

More than 43 percent of the decorated sherds in the 2017 assemblage have brushed or brushedincised decorative elements (Table A1-5); 51 percent of the sherds in the earlier sample have brushed, brushed-incised, and brushed-punctated decorative elements. The percentage ranges are consistent with a Middle Caddo period component at the Mike Myers site.

Table A1-5. Decorated sherds in the 2017 investigations at the Mike Myers site.

Decorative method and

Rim Body

$\mathrm{N}$ decorative element

\section{Utility ware}

\section{Brushed}

parallel brushed

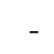

Brushed-Incised

opposed brushing with overlying parallel incised lines

parallel brushed-incised

-

Incised

parallel incised lines

straight incised line (overhanging line)

\section{Incised-Punctated}

band punctated

\section{Punctated}

fingernail punctated rows

tool punctated rows

$\begin{array}{lll}- & 1 & 1 \\ - & 1 & 1 \\ & & \\ 1 & - & 1 \\ - & & \\ - & 4 & 4 \\ & 2 & 2\end{array}$

Fine ware

\section{Engraved}

diagonal opposed engraved lines horizontal zone filled with diagonal engraved lines horizontal and vertical engraved lines with hatched corners straight engraved line

Totals

\begin{tabular}{lll}
- & 1 & 1 \\
1 & - & 1 \\
- & 1 & 1 \\
- & 1 & 1 \\
\hline
\end{tabular}

2
21

One incised sherd with an overhanging incised line is from a Coles Creek Incised, var. unspecified vessel, dating to the Early Caddo period, ca. A.D. 900-1050. Another sherd that is part of this Caddo component is a band punctated rim sherd in ST 50 (40-60 cm bs) (Figure A1-2a). Band punctated sherds have parallel or horizontal incised lines with bands of impressed triangles (Goode et al. 2015:72 and 
Figure 34). Girard (2009:28) has suggested that these sherds with impressed punctations between incised lines are a regional variant of Coles Creek Incised, var. Coles Creek; they are common in Early Caddo period contexts at the Mounds Plantation site (16CD12) along the Red River in Northwest Louisiana (Figure A1-3).

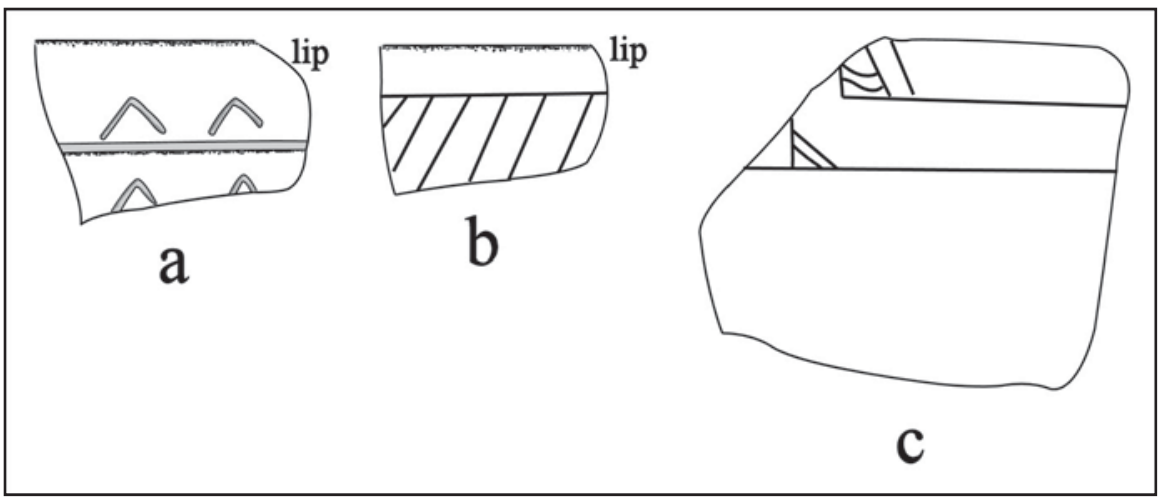

Figure A1-2. Selected sherd decorative elements in the 2017 investigations at the Mike Myers site: a, band punctated; b-c, engraved.

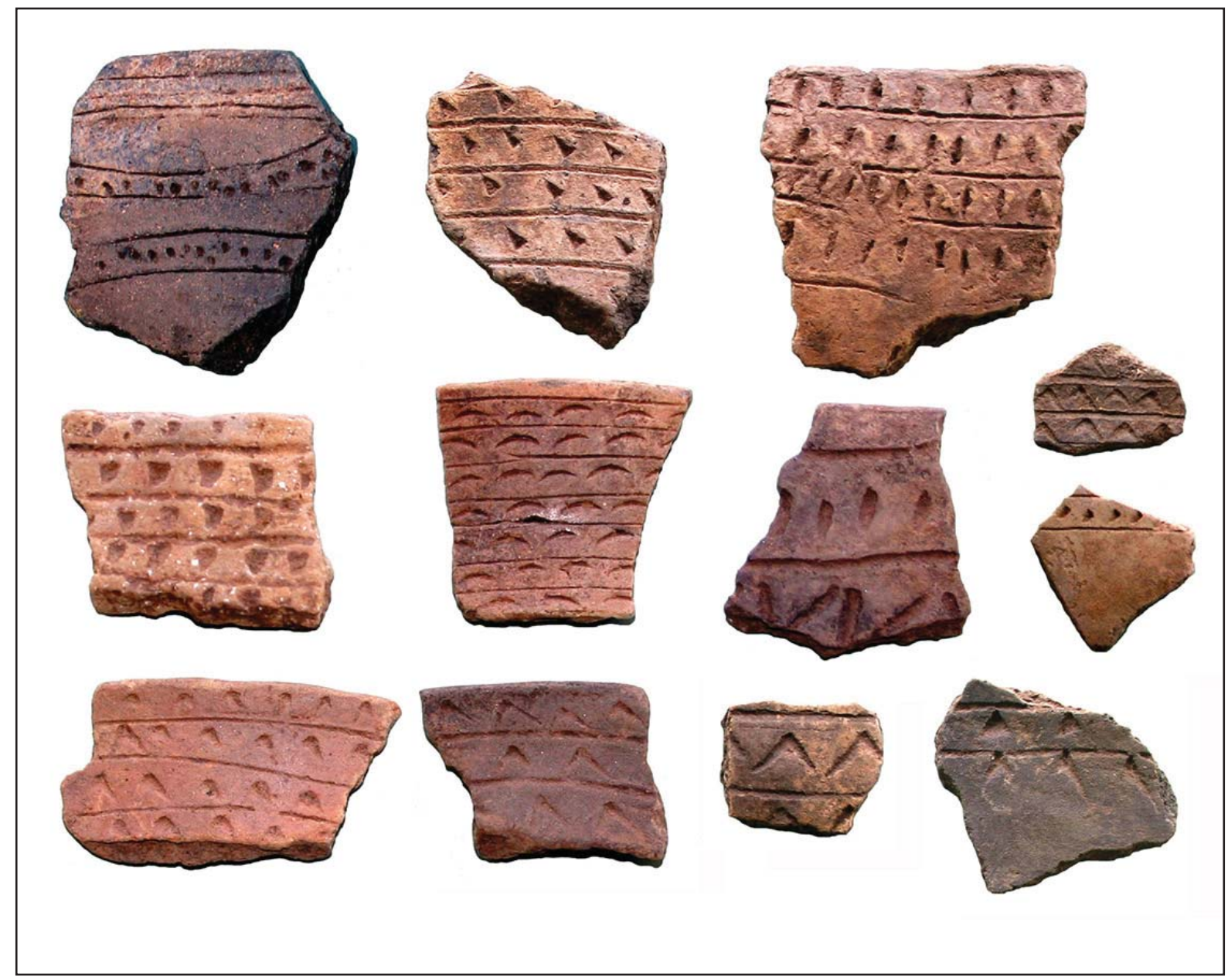

Figure A1-3. Selected incised-punctated and band punctated sherds from the Mounds Plantation site, Caddo Parish, Louisiana. Photograph courtesy of Jeffrey S. Girard. 
The punctated sherds in this collection have either rows of fingernail or tool punctations (see Table A1-5). The last of the engraved sherds is from a globular carinated bowl with horizontal, vertical, and diagonal engraved lines, and there are hatched curvilinear lines at the intersection of horizontal and vertical lines (see Figure A1-2c). The vessel form and the hatched element are stylistically consistent with Poynor Engraved vessels from Frankston phase components in the Neches River basin.

Sherds from fine ware vessels comprise 17 percent of the decorated sherds in the 2017 sample. One $\operatorname{rim}$ (ST 51, 0-20 cm bs) has a horizontal engraved zone filled with diagonal engraved lines (see Figure A1-2b), while a body sherd (ST 56, 0-20 cm bs) has diagonal opposed engraved lines. The remaining fine ware sherd has a single straight engraved line (see Table A1-5).

The decorated sherds in the ceramic assemblage are dominated by utility wares ( 76.3 percent), particularly sherds with brushed and brushed-incised decorative elements, although sherds from incised or punctated vessels are also common at the Mike Myers site (Table A1-6). Almost all the fine wares are from engraved vessels. The different kinds of decorated sherds, as well as the proportions of brushed sherds, suggest that the main ancestral Caddo occupation took place during the Middle Caddo period. Other decorated Caddo vessel sherds are indicative of some use of the site between ca. A.D. 1000-1200, A.D. $1400-1680$, and after ca. A.D. 1680.

Table A1-6. Summary of decorated sherds from the Mike Myers site.

\begin{tabular}{lll}
\hline Decorative method & Number & Percent \\
\hline Utility Ware & & \\
Appliqued & 1 & 0.9 \\
Brushed & 39 & 34.2 \\
Brushed-Incised & 14 & 12.3 \\
Brushed-Punctated & 3 & 2.6 \\
Grooved & 1 & 0.9 \\
Incised & 12 & 10.5 \\
Incised-Punctated & 1 & 0.9 \\
Pinched & 1 & 0.9 \\
Punctated & 13 & 11.4 \\
Fine Ware & & \\
Engraved & & 26.8 \\
Trailed & 1 & 0.9 \\
\hline Total & 114 & 100.0 \\
\hline
\end{tabular}

Chipped stone tools recovered in the 2017 work at the Mike Myers site include one arrow point, three dart points, two scrapers, and one flake tool. The arrow point (ST 60, 40-60 cm bs) is the straight stem to an Alba point of Early Caddo period age (ca. A.D. 900-1200) made from a translucent gray chert that likely originated in Central Texas. The stem width of the point is $10.7 \mathrm{~mm}$ and the stem is $4.9 \mathrm{~mm}$ thick.

A Kent dart point made from petrified wood was recovered in ST $56(60-80 \mathrm{~cm} \mathrm{bs})$, in probable Woodland period deposits. The point is $51.6 \mathrm{~mm}$ in length, $25.8 \mathrm{~mm}$ in width, with a $19.4 \mathrm{~mm}$ stem width, and the point is $11.0 \mathrm{~mm}$ thick. This same provenience has a light gray dart point tip fragment (3.8 $\mathrm{mm}$ in thickness). Another dart point tip ( $6.0 \mathrm{~mm}$ in thickness $)$, made from a yellowish-gray chert, was recovered in ST 52, 40-60 cm bs. 
The first of the scraping tools is from ST $54(0-20 \mathrm{~cm}$ bs). It is a bilateral side scraper with a graver peak manufactured from a light gray non-local chert non-cortical flake. The use-worn length is 38.0+ $\mathrm{mm}$. The second scraper (ST 62, 80-93 cm bs) is an end scraper on a cortical flake of non-local grayishbrown chert. It has a total use-worn length of $31.4 \mathrm{~mm}$. The one flake tool (ST 51, 60-80 cm) is a unilateral expedient tool on a non-cortical and non-local gray chert flake; its use-worn length is $24.0+\mathrm{mm}$.

The lithic debris and cores in the 2017 excavated sample includes a number of different kinds and colors of raw materials selected for reduction and tool manufacture (Table A1-7). The principal raw materials used were quartzite, petrified wood, gray chert, and light gray chert.

Table A1-7. Lithic debris and cores recovered in the 2017 investigations at the Mike Myers site.

\begin{tabular}{llc}
\hline Raw Material & N & Percent Cortical \\
\hline Chalcedony & 1 & - \\
Petrified wood & 15 & 60.0 \\
Quartzite & 18 & 27.8 \\
brown chert & 2 & - \\
brownish-gray chert & 3 & 33.3 \\
light gray chert & 9 & 22.2 \\
gray chert & 10 & 20.0 \\
translucent gray chert & 3 & 33.3 \\
dark gray chert & 7 & - \\
translucent dark gray chert & 1 & - \\
translucent grayish-brown chert & 1 & - \\
grayish-brown chert & 2 & 50.0 \\
dark grayish-brown chert & 1 & - \\
red chert & 1 & 100.0 \\
reddish-gray chert & 1 & - \\
yellowish-red chert & 2 & 50.0 \\
yellowish-gray chert & 1 & - \\
yellow chert & 2 & - \\
Manning Fused Glass & & - \\
\hline Totals & 3 & 27.7 \\
\hline
\end{tabular}

About 28 percent of the lithic debris has cortical remnants, almost all with a smooth cortex, suggesting that they were primarily detached from stream-rolled pebbles in gravel beds, mostly available in nearby Neches River gravel sources. Local raw materials (see Table 11 in main article by Perttula and Stingley) comprise about 55 percent of the lithic debris sample, and non-local cherts comprise another 41 percent of the lithic debris, much of which may have originated in Red River gravels or Central Texas source areas. Manning Fused Glass, represented by 3.6 percent of the lithic debris sample (see Table A17), is a regionally available raw material present in Manning Formation sources about 70-80 km south of the Bowles Creek valley (Brown 1976:Figure 3).

Investigations at the Mike Myers (41CE481) site in 2016 and 2017 have recovered a substantial artifact assemblage, including plain and decorated ceramic vessel sherds, chipped and ground stone tools, lithic debris from tool manufacture, wood charcoal and nutshell, and burned and unburned animal bones from likely preserved cultural features in archaeological deposits in the Bowles Creek valley. These artifacts have been recovered in surface collections, a substantial number of shovel tests, and the excavation of a $3 \times 1 \mathrm{~m}$ unit in one part of the site (Table A1-8). 
Table A1-8. Distribution of Artifacts in all investigations at the Mike Myers site (41CE481).

\begin{tabular}{|c|c|c|c|c|c|c|c|c|c|c|}
\hline Prov. & PS & DS & AP & $\mathrm{DP}$ & Bif & FT & $\mathrm{LD}$ & $\mathrm{AB}$ & $\begin{array}{l}\mathrm{WC} / \\
\mathrm{NS}\end{array}$ & $\mathrm{N}$ \\
\hline $\begin{array}{l}\text { Surface, } \\
2016\end{array}$ & 28 & 19 & 2 & - & - & 1 & 28 & - & $-/-$ & 78 \\
\hline $\begin{array}{l}\text { Surface, } \\
2017\end{array}$ & 21 & 7 & - & - & - & - & 5 & - & $-/-$ & 33 \\
\hline $\begin{array}{l}\text { ST 2-46, } \\
101-105\end{array}$ & 114 & 48 & 2 & 7 & 4 & 3 & 353 & 115 & $10 / 11$ & 668 \\
\hline Units 1-3 & 53 & 25 & 1 & 1 & - & 1 & 273 & 81 & $2 / 11$ & 447 \\
\hline ST 50-64 & 50 & 16 & 1 & 3 & - & 3 & 76 & 19 & $3 /-$ & $172 *$ \\
\hline Totals & 316 & 115 & 6 & 11 & 4 & 8 & 735 & 215 & $15 / 22$ & 1447 \\
\hline
\end{tabular}

*includes a nutting stone from ST $54,20-40 \mathrm{~cm}$ bs

$\mathrm{PS}=$ plain sherd; $\mathrm{DS}=$ decorated sherd; $\mathrm{AP}=$ arrow point; $\mathrm{DP}=$ dart point; $\mathrm{BIF}=$ biface; $\mathrm{FT}=$ flake tool; $\mathrm{LD}=$ lithic debris; $\mathrm{AB}=$ animal bone; $\mathrm{WC}=$ wood charcoal; $\mathrm{NS}=$ nutshell

Based on the recovery of plain and decorated ceramic sherds, dart points, and arrow points in the archaeological deposits, the recognized components include Late Archaic (marked by a Yarbrough point), early and late Woodland (marked by a Steiner arrow point), the Early Caddo period (marked by an Alba arrow point, a band punctated sherd and a Coles Creek Incised sherd), the Middle Caddo period, the Late Caddo period (marked by one cf. Poynor Engraved sherd), and during Historic Caddo period times (marked by sherds of Lindsey Grooved and Keno Trailed), The early Woodland and Middle Caddo components appear to represent the principal periods of use by ancestral Caddo peoples, with the early Woodland component present in the northern part of the site, and the Middle Caddo period component in both the northern and southern parts of the Mike Myers site.

\section{References Cited}

Brown, K. M.

1976 Fused Volcanic Glass from the Manning Formation. Bulletin of the Texas Archeological Society 47:189-207.

Girard, J. S.

2009 Regional Archaeology Program Management Unit 1, Twentieth Annual Report. Northwestern State University of Louisiana, Natchitoches. Report on file with the Louisiana Division of Archaeology, Department of Culture, Recreation and Tourism, Baton Rouge.

Goode, G. T., T. K. Perttula, L. L. Bush, S. Marceaux, L. Schniebs, and J. Todd

2015 Excavations at the Early Caddo Period Mound Pond Site (41HS12) in Harrison County, Texas. Special Publication No. 38. Friends of Northeast Texas Archaeology, Austin and Pittsburg. 